\title{
İç Mekanlarda Asma Tavan Uygulamaları
}

\author{
Merve Betül GÜLER ${ }^{1}$, Esin KASAPOĞLU²
}

Öz

İç mekandaki en önemli bitiş yüzeylerinden biri olan asma tavanlar, kullanıldığı mekanlarda mevcut bir tavanın altında; tavandan geçen tesisatları gizleyerek dekoratif bir görünüm kazandıran, akustik kontrol, yangın koruması gibi işlevsellikler sağlamak amacıyla uygulanan, çeşitli taşıyıcı sistem seçenekleri olan, kaplama malzemesi olarak birçok alternatifi bulunan yapı elemanlarıdır. Günümüz mimarisinde, yapılarda (konutlar, hastaneler, eğitim binaları, spor salonları, endüstriyel yapılar, ulaşım yapıları, alışveriş merkezleri, ofisler, restoran ve kafeler gibi) asma tavan sistemleri sıklıkla uygulanmaktadır. Bu sebeple asma tavanı oluşturan bileşenlerin iyi bilinmesi, uygulamaların doğru yapılması önemlidir. Tavan kaplama malzeme seçenek ve olanaklarının artmasına rağmen, doğru olarak kullanılması ve kullanıldığı mekandaki işleve uygun olarak seçimi yanında, doğru uygulama yapılması da önemlidir. Tasarımcı mutlaka en uygun asma tavan sistemine karar vermeli ve uygulanmasını sağlamalıdır. Malzemelerin bu denli artması, taşıyıcıların çeşitlenmesi bunların bir bütünlük içinde ele alınarak irdelenmesi zorunluluğunu da beraberinde getirmektedir. Bu çalışma kapsamında, asma tavan sistemlerinin tanıtılması, yapıya katkılarının ortaya konması ve uygulama biçimlerinin sistemli bir şekilde, bir derleme çalışması çerçevesinde ele alınması amaçlanmaktadır. Asma tavanların tanımından başlayarak, yapı içinde üstlendikleri işlevler, çeşitleri ve uygulama biçimleri bir bütün olarak ele alınacaktır.

Anahtar Kelimeler: Asma Tavan, Asma Tavan Çeşitleri, Asma Tavan Bileşenleri, Asma Tavan Kaplamaları, Asma Tavan Taşıyıcıları

\section{Suspended Ceiling Applications in Interior Spaces}

\begin{abstract}
\footnotetext{
${ }^{1}$ ASPEN Yapı ve Zemin Sistemleri San. ve Tic. A.Ş.

2 İstanbul Kültür Üniversitesi, Mimarlık Fakültesi, Mimarlık Bölümü,

*İlgili yazar/Corresponding Author: ekasapoglu@iku.edu.tr

Gönderim Tarihi / Received Date: 25.03.2020

Kabul Tarihi / Accepted Date: 31.03.2021
}

Suspended ceilings, one of the most important finish surfaces in the interior, are under an existing ceiling in the spaces where it is used; they are the building elements that provide a decorative appearance by hiding the installations passing through the ceiling, which are applied to provide functionality such as acoustic control and fire protection, have various carrier system options and have many alternatives as coating materials. In today's architecture, suspended ceiling systems are frequently used in buildings (residences, hospitals, educational buildings, sports halls, industrial buildings, transportation structures, shopping centers, offices, restaurants, and cafes). For this reason, it is important to know the components that make up the suspended ceiling and to make the applications correctly. Although ceiling coating material options and possibilities increase, it is also important to use it correctly and to make the right application as well as to choose it according to the function in the place where it is used. The designer must absolutely decide on the most suitable suspended ceiling system and ensure its implementation. This increase in materials and diversification of carriers bring with it the necessity to consider them in an integrity. Within the scope of this study, it is aimed to introduce suspended ceiling systems, to reveal their contribution to buildings and to discuss the application forms in a systematic manner within the framework of a compilation study. Starting from the definition of suspended 
ceilings, their functions, types, and application forms they undertake in the building will be discussed.

Keywords: Suspended Ceiling, Suspended Ceiling Types, Suspended Ceiling Elements, Suspended Ceiling Coatings, Suspended Ceiling Carriers

\section{Giriş}

Asma tavanlar bir mekanda uygun fiziki ortamın oluşturulmasına katkıda bulunan elemanlardır. İnsanların toplu halde yaşadıkları ve kullandıkları toplantı ve konferans salonları, oteller, ofisler, restoran ve kafeler, hastane, alışveriş merkezleri gibi binalarda yaygın olarak kullanılırlar. Mekana estetik etkileri olması yanında, ısı yalıtımı, ses yalıtımı, aydınlatma, havalandırma gibi konfor koşullarının sağlanmasına katkıda bulunurken, tesisatları gizlenmek, düz bir tavan elde etmek gibi çeşitli amaçlarla uygulanabilmektedirler. Asma tavanlardan istenen başarımın elde edilebilmesi için bir bütün olarak tanınması, çeşitleri, bileşenleri, taşıyıcıları ve uygulama yöntemlerinin beraber incelenmesini gerektirmektedir.

Yapılan kaynak taramalarında elde edilen sonuçlara göre, asma tavan sistemleri, bütüncül bir şekilde ele alınmamış, yeteri kadar açıklanmamış, bilimsel olarak sistemli bir şekilde ortaya konmamıştır. Bu çalışma yapılırken, doğrudan ya da dolaylı yollardan, çeşitli üniversitelerin (İstanbul Teknik Üniversitesi, İstanbul Kültür Üniversitesi, Yıldız Teknik Üniversitesi, Bilgi Üniversitesi gibi) kütüphaneleri ve uzaktan erişim arşivleri taranmıştır. Yüksek Öğretim Kurulu (YÖK) Dokümantasyon Merkezinde araştırmalar yapılmış, çok sayıda tez gözden geçirilmiştir. Çalışma kapsamında, asma tavan sistemlerinin tanıtılması, yapıya katkılarının ortaya konması ve uygulama biçimlerinin sistemli bir şekilde, bir derleme çalışması çerçevesinde ele alınması amaçlanmaktadır. Asma tavanların tanımından başlayarak, yapı içinde üstlendikleri işlevler, çeşitleri ve uygulama biçimleri bir bütün olarak ele alınmaktadır.

\section{Asma Tavan Sistemleri}

Tavan; örtülü bir yerin üstündeki döşemenin alt yüzeyi; taban karşıtı olarak ifade edilmektedir (Hasol, 1990, s. 506). Döşeme veya çatının alt yüzünü örten ve alt taraftan bakıldığında görünen yüzeyi oluşturan yapı öğesidir (TS EN 13964, 2014, s.8). Döşemenin altında görünen kısım tavan olarak adlandırılmakta olup, sadece altı kullanılan mekanlar için geçerli bir kavramdır. Asma tavanlar; mevcut bir tavanın altına daha iyi bir görünüş vermek amacıyla, döşemeye asılarak yapılan ikinci tavanlardır (Kızıldeli, 2002, s.46). Mevcut taşıyıcı sisteme sıva yapılması dışında, tavana başka bir malzemenin aralıklı ya da doğrudan tespit edilmesi olarak da tanımlanmaktadır (Toydemir vd. 2000, s.364). Bir başka tanıma göre ise, tavan veya çatı ile alt konstrüksiyonu arasında boşluk bırakılarak yapılan tavan kaplamaları "asma tavan" olarak adlandırılmaktadır (Allen ve Iano, 2009, s. 925). TSE EN 13964'te (2014, s.8) asma tavan; 'yük taşıyıcı yapı elemanına (duvar, çatı, kiriş ve döşeme) tespit edilmiş bir askı sistemi veya doğrudan monte edilmiş asma tavan taşıyıcı sistemi veya tavan çevre profili vasıtasıyla, döşeme veya çatıdan belirli bir mesafeden aşağıdan asıımış tavan' olarak tanımlanmaktadır (Fot. 1). 

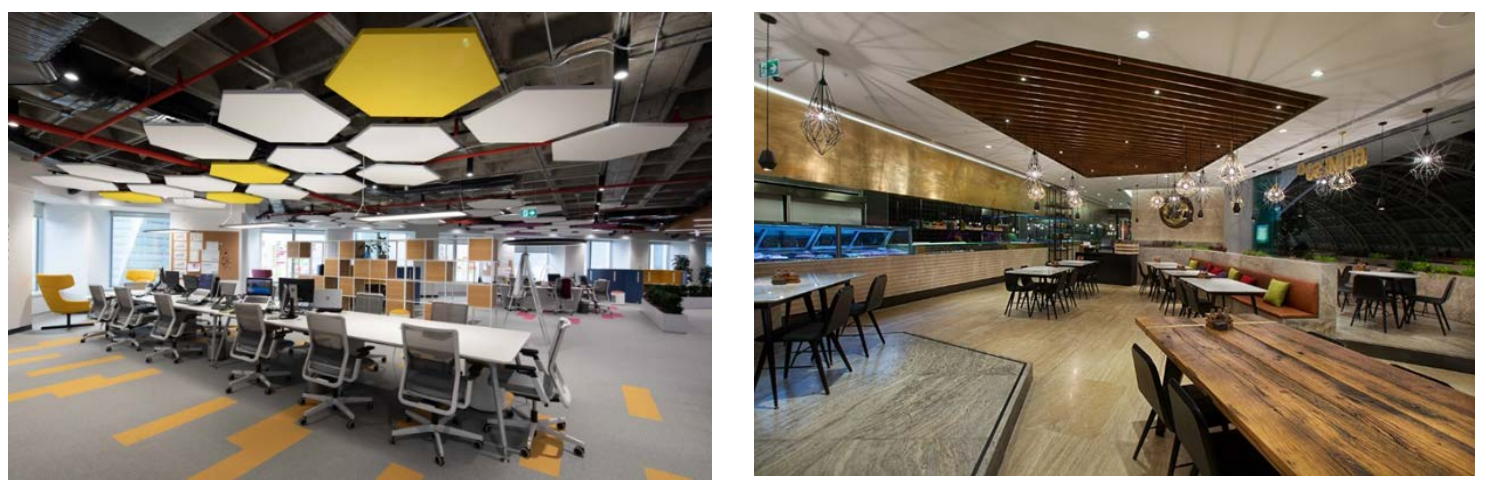

Fot. 1: Açık ofislerde kullanılan ve kafeteryalarda kullanılan asma tavan örnekleri (URL 1)

Yapısal olmayan elemanlardan asma tavan, bütünsellik sağlanması ve bazı gereksinimlerden dolayı, kullanılması son derece önemli yapı elemanlarıdır (Tichelmann ve Pfau, 2012, s.40). Altı düz olan ya da olmayan, döşemenin alt ve üst hacimleri arasında farklı sorunların mevcut olduğu ya da alttaki mekan yönünden gerekli ve önemli bazı düzenlemelerin yapılabilmesi asma tavan ile çözümlenmektedir (Toydemir vd. 2000, s. 363). Tasarımcının elinde çok önemli bir araç olma özelliğine sahiptir. Aydınlatma elemanları, yağmurlama başlıkları, ses sistemleri ve yangın belirleme cihazları asma tavanlara yerleştirilebilmektedir (Allen ve lano, 2009, s. 925).

Asma tavanlar, günümüzde konutlarda, ortak alanlar ve ıslak hacimlerde kullanılmakla birlikte, esas olarak endüstriyel ölçekli (sağlık yapıları, ofisler, eğitim yapıları, ulaşım tesisleri, fabrika binaları vs.) yapılarda daha fazla yer almaktadır. Asma tavanlarda yer alan malzemelerin beklentileri karşılaması; kullanım amaçlarına ve yerlerine göre, beklentilerin öncelik sırasının belirlenmesi ve buna göre seçiminin yapılmasına bağlıdır. Asma tavan sistemlerinden beklentiler aşağıda alt başlıklar halinde ele alınmıştır.

\subsection{Görünüş, Yüzey Özellikleri ve Estetik}

Bir yapıda kullanım alanı açısından asma tavanlar son derece büyük bir alana sahiptir. İç mekanlardaki tavan kaplamalarının, duvar ve döşeme ile iç mekanı oluşturarak, tasarımın bütünlüğünü sağlayan önemli etkiler yaratması, içerisinde bulunduğu binanın estetik etkilerine olumlu bir katkı yapacak nitelikte olması beklenmektedir (Coşar, 2002, s.10). Her malzemenin dokusu, görünüşü ve özelliği farklıdır. Tavan bir mekana girildiğinde en etkili yüzeylerden biridir. Dolayısıyla doğrudan estetik olarak mekana katkıda bulunmaktadır. Özellikle, tesisatın gizlenmesini sağladığı için mekan algısını doğrudan değiştiren bir etkisi olmaktadır. Bu sebeple asma tavanlarda malzeme seçilirken fiziksel özelliklerine bakıldığı kadar, görsel olarak etkisine de bakılmalıdır. Tavan yüzeyini, mekan kimliği üzerinde ve istenilen etkinin yaratılmasında önemli etkilere sahiptir (Hegger vd. 2006, s.167-169).

\subsection{Akustik Beklentiler}

Asma tavanlarda yapı içinde işitsel konfor koşullarının sağlanması, hacim içinde uygun fiziki ortam koşullarının yaratılmasında önemli rol oynamaktadır. Yapılan araştırmalar, akustiği yetersiz bir okulda, sınıflarda eğitim gören çocukların öğrenme kabiliyetlerinin düştüğünü göstermektedir (Gürel, 2007, s.1). Başka bir çalışmanın sonucuna göre, çocukların zıplaması ve koşması gibi çarpma seslerinin, düşük frekanstaki baskın ses enerjisine sahip seslerin, apartmandaki en rahatsız edici gürültü olarak algılanmakta ve çeşitli sosyal sorunlara neden olmaktadır (Ryu vd. 2018, s.1). Ses dalgasının bir mekandan diğerine asma tavan boşluğu içinde yayılması, yukardaki ve aşağıdaki mekanlara kolaylıkla iletilmesi mümkün olabilmektedir. Kullanılan kaplama malzemesinin birim ağırlığı düşük bir akustik levha olması ya da mineral yün seçilmesi 
gibi farklılıklar iletilen sesin düzeyini farklılaştırmaktadır. Özellikle çok düşük ses iletiminin istendiği mekanlarda kullanılan kaplama malzemesi ve bağlantı detayları daha da önem kazanmaktadır (Cavanaugh ve Wilkes, 1999, s.1-54). Asma tavanlarda malzeme seçiminin gürültü denetiminin sağlayacak şekilde yürütülmesi önemlidir. Bu çerçevede hacim akustiğinin intiyaçlarına uygun nicelik ve nitelikte malzemelerin kullanılması hacmin işitsel konfor koşullarını olumlu yönde etkilemektedir. Asma tavanlar yansıyan ses düzeyini azaltmak için gerekli yüzey yutuculuğunun sağlanmasında en elverişli elemanlardır (Mütevellioğlu, 1995, s.26).

\subsection{Işık Yansıtıcılığı}

Iyi bir ışıklı ortam yaratmanın insan vücudu ve ruhu üzerinde etkisi vardır. Aydınlatma görsel aktivitelerin etkinliğini belirlemekte, yaşam süreçlerini düzenlemektedir. Aydınlatılmış alanların ve nesnelerin algılanmasını, duyguları, mekanın kullanıcılarının ruh hallerini, ve davranışlarını etkileyebilmektedir. Aynı zamanda aydınlatılmış yerlerin estetik olarak algılanması üzerinde de etkileri olmaktadır (Pracki vd. 2020, s. 4744). Cisimler spektrumdaki bazı ışınları belirli oranda yutarlar, bazı ışınları da belirli oranlarda yansıtırlar. Beyaz cisim en çok yansıtan, siyah ise en çok emen renklerdir (Erdem, 2017, s.36). Asma tavan malzemesinin yüzeyinde yansıtma özelliği talep ediliyorsa buna uygun renkte bir tavan malzemesi kullanılmalıdır. Asma tavanlardan yüksek seviyede ışığın yansıtılması, iç mekanlarda doğru seviyede aydınlatmanın elde edilmesine katkı sağlarken, aynı zamanda fazla elektrik enerjinin tüketiminin azaltılmasına da yardımcı olmaktadır. Asma tavan malzemelerinde EN ISO 7724-2 ve 7724-3 (TS EN 13964, 2014, s. 8) olarak ışığın yansıması konusunda, akreditasyonlu laboratuvarlarda kapsamlı testler uygulanmalıdır.

\subsection{Yangın Dayanımı ve Yangın Koruması}

Yapılarda çıkan yangınlar çok hızı şekilde ilerleyerek yıkıcı sonuçlara yol açabilir. Sadece malzeme açısından bir yapının yangın riski, yapı malzemesinin yangını başlatmasının yanı sıra, herhangi bir nedenle çıkan yangın karşısındaki tutumuna da bağlı olmaktadır. Malzeme yanmayabilmekte, alev almayabilmekte ama yine de yangın riski oluşturabilmektedir. Örneğin, bazı malzemeler yangının yayılmasına neden olan duman ile zehirli ve zehirsiz gaz çıkarmaktadırlar (Toydemir vd. 2000, s.75). Asma tavan sistemindeki boşluk içinde duman bir mekandan diğerine iletilebilmektedir. Tavan paneller arasında bırakılan boşluk, birleşim detayları duman sızdırma oranını belirlemektedir (Chou vd., 2020, s. 7244). Yapısal elemanları yangınının etkilerinden korumanın bir yolu, yanmaz asma tavan malzemeleri kullanmaktır. Asma tavanların yangına dayanımı arttıkça iletişim, havalandırma ve iklimlendirme sistemleri ile elektrik tesisatının da yangına karşı korunması sağlanmaktadır (Gravit ve Golup, 2018, s.7585). Asma tavanlarda kullanılan malzemeler seçilirken yangın dayanım süreleri de göz önünde bulundurulmalı, kullanılan alana uygun malzemeler tercih edilmelidir.

\subsection{Nem Dayanımı}

Yapılarda nem; küf, mantar, bakteri vb. mikrobiyolojik aktivitelerin oluşmasına sebep olmaktadır. Ortamın hava kalitesi olumsuz etkilenmekte ve insan sağlığını tehdit etmektedir (Yıldız ve Dal, 2016, s. 25-37). Asma tavanlar, neme maruz kaldığında dayanıklı değildirler. Nem etkisi altında kaldıklarında asma tavan bileşen takımlarında ve taşıyıcı sisteminde dayanım kaybı görülebilmekte, sarkma oluşabilmektedir. Öte yandan, asma tavanlar nem etkisi altında kaldıklarında tehlikeli bileşiklerin gazlarını çıkarabilir, kırıldığında veya kesildiğinde sağlığa zararlı havadaki partikülleri salabilir, nem tutma yoluyla küf ve küf oluşumunu teşvik edebilmekte, kaplama yüzeyinde leke oluşumuna neden olabilmektedirler (Yıldırım, 2018, s. 7360). Asma tavan bileşenleri ve malzemeleri seçilirken, uygulandıkları mekanda su ve neme maruz kalma olasılıkları ile neme karşı dayanımları göz önünde bulundurulmalıdır. 


\subsection{Isı Yalıtımı}

Asma tavanlarda kullanılan malzemelerin, Isı yalıtım malzemeleri olmamalarına rağmen hem bina genelinde hem de bina içindeki farklı ortamlar arasında yüksek ISı yalıtım performansı sağlayarak binanın enerji intiyacına az da olsa yardımcı olması beklenmektedir. Asma tavan bir çatı altında yer alıyor ise buraya yerleştirilecek uygun kalınlıkta bir ısı yalıtım malzemesi ile ısıtma veya soğutma düşünülen hacim küçültülmüş olmaktadır. Genel olarak; malzeme seçimi yapılırken, malzemenin kalınlığı ve gözenek çapı azalırsa, ısı iletkenliğinin artmakta olduğuna dikkat edilmelidir. Malzemenin ısısı ve hacim ağırlığının artması durumunda, ısı iletkenliği de artmaktadır (Ülker, 2009, s.26).

\subsection{Sökülebilirlik}

Tavan malzemesinin sökülebilir olmasının ilk ve en önemli avantajı, asma tavan içinden geçen tesisata istenildiği takdirde kolayca ulaşılabilir olmasıdır. Bu tür tesisata bakım ve onarım gerektiğinde istenildiği takdirde tavanın içerisine müdahale edilebilir ve sorun çözülebilir. Ayrıca sökülebilirlik sayesinde tavanda herhangi bir sızıntı, tesisatta kaçak $\mathrm{vb}$. olduğunda tüm asma tavana zarar vermeden kolayca ilgili yere ulaşılabilir. Sökülebilirliğin sağladığı esneklik sayesinde, tavan kaplama malzemesi zarar gördüğünde ya da kırıldığında, eskidiğinde, ortam (dekorasyon) değiştiğinde, yönetmelikler ve standartlarda herhangi bir değişiklik olduğunda, kullanıcı değişimi ya da kullanıcının taleplerinin farklılaşması durumunda değişiklik kolaylıkla yerine getirilebilmektedir.

\subsection{Hijyen, Küf ve Bakteri Direnci}

Piyasadaki birçok asma tavan paneli, havadaki parçacıkların veya kimyasalların salınması yoluyla insan sağlığını riske atan malzemeler içerebilir (Yıldırım, 2018, s. 7361). Küfün oluşması için havasız ve hava sirkülasyonun olmadığı aydınlık olmayan, buna ek olarak sıcaklık farklılıklarının yüksek olduğu nemli ortamlar gereklidir. Küf ve bakterinin olmaması istenen mekanlarda, malzeme seçilirken inorganik yapıda malzemeler seçilmelidir. Kullanılan asma tavan malzemesinin bakteri ve mantar oluşumuna dayanıklı, tavan yüzeyini koruyan ve tavan boşluğu üzerindeki olumsuz etkileri ortadan kaldırması beklenmektedir.

\subsection{Teknik Donatı Entegrasyonu}

Asma tavanlarda birlikte kullanılan, benzer olmayan özelliklere sahip malzemelerin hem birbiriyle uyumlu hem de birlikte olduğu malzeme ya da sistemlerle uyumlu olması gerekmektedir. Asma tavan sistemlerinin elektrik, sıhhi tesisat, mekanik tesisat, aydınlatma, ısıtma ve yangın söndürme sistemleriyle entegrasyonu son derece önemlidir. Çünkü bu sistemlerin çoğu yapılar gereği tavanın üstünde yer almaktadır. Asma tavan sisteminin teknik donatılarla birlikte çalışması, estetik-görsel açıdan iyi sonuçların elde edilmesini, aynı zamanda erişim kolaylığı sağlamasını, bakımını kolaylaştırarak, işlevsellik açısından yapıya katkıda bulunmasını sağlamaktadır.

\subsection{Uzun Ömür}

Asma tavan taşıyıcı ve kullanılan malzemelerin tavsiye edilen şekilde normal bakımları yapıldığında performans özelliklerini koruması beklenmektedir. Asma tavan kaplama bileşeni ve asma tavan taşıyıcı sistemine ait görünür yüzeylerin temizlenebilir olup olmadığını ve bu yüzeyler temizlenebiliyorsa hangi temizleme tekniğinin uygulanması gerektiği ve hangi sınırlamaların uygulanacağı asma tavan sağlayıcısı tarafından kullanıcıya bildirilmelidir. Asma tavan kaplama bileşeni ve asma tavan taşıyıcı sistemine ait görünür yüzeylerin tekrar boyanabilir olup olmadığı ve bu yüzeylerin tekrar 
boyanabilir olması halinde hangi malzemeler ve teknikleri tavsiye edildiği ve varsa tavan performansına ilişkin hangi özelliklerin etkilenebileceği de belirtilmelidir.

\subsection{Darbe Dayanımı}

Binalarda asma tavanlara birçok bina içi tesisatın gizlenmesi sağlanmaktadır. Bu tür donanımlara ulaşmak için asma tavanlara sık sık erişim sağlanması gerekebilir. Bahsedilen erişimler sırasında asma tavan sistemi veya malzemeleri hasar görebilir, gözle görülür olumsuz hasarlar meydana gelebilir. Darbeye dayanıklı asma tavan malzemesinin kullanılması hem oluşabilecek hasarın azaltılmasına hem de bina kullanıcısı için kaliteli bir ortam yaratılmasına katkıda bulunmaktadır. Bir asma tavan sisteminin içeriden ve aşağıdan gelebilecek darbelere karşı mukavemetinin yüksek olması beklenmektedir. Asma tavanın çökmesi, ani bir yıkım anlamına gelmekte ve sonuçları ağır olabilmektedir (Wieckowski vd. 2018, s.107-116).

\subsection{2 İç Ortam Hava Kalitesi}

Bir binadaki döşeme, cila, boya, yapıştırıcı, gibi yapı malzemeleri, mobilyalar, bina kullanıcılarının nefes alma, terleme gibi yaşamsal faaliyetleri ile yemek pişirme, ısıtma, temizlik gibi günlük faaliyetler iç ortam havasına çeşitli zararlı madde salınımı yapmaktadır. Cildi, gözleri ve solunum sistemini tahriş eden aynı havadaki tozlar, uygun olmayan şekilde bertaraf edilerek çevreye salındığında ekolojik riskler oluşturmaktadır (Yıldırım, 2018, s. 7360). Asma tavan kaplamalarının iç ortam hava kalitesine katkıda bulunması beklenmektedir. İç ortamın hava kalitesini arttırmak için öncelikli olarak doğru havalandırma sağlanmalıdır. Tavan kaplama malzemesi seçerken uçucu organik bileşen salınımı düşük malzemeler tercih edilmelidir.

\subsection{Sismik Beklentiler}

Asma tavan sistemi, sismik olaylar sırasında büyük hasara neden olabilecek ve güvenliği tehlikeye sokabilecek ve binaların sürekli çalışmasını engelleyebilecek yapısal olmayan bileşenlerden biridir (Ryu ve Reinhorn, 2019, s.592). Dünya genelinde depremler sırasında ve sonrasında oluşan hasarlar gözlendiğinde, yapısal olmayan bileşenlerin hasar görmesinin işlevselliği ciddi şekilde etkileyebildiği, yaralanmalara veya ölümlere yol açtığı görülmüştür (Brandolese, vd. 2019, s.219). Panellerin yerinden çıkması ve kırıması, tavan ızgara elemanlarının ve bağlantılarının burkulması gibi daha düşük seviyede hasarlar da oluşabilmektedir (Dhakal, 2011, s. 62) (Soroushian vd. 2015, s. 784). Orta derecede sallayarak bile hafif akustik paneller kolayca yerinden çıkabilir (Yao, 2000, s. 6). Deprem bölgesinde inşa edilen bir hastanede sismik bir asma tavan sistemi kullanılmamışsa, sarsıntı esnasında tavanın hastaların üzerine düştüğü ve yaralanmalara neden olması karşı karşıya kalınabilecek sonuçlardan bir diğeridir (URL 2). Bu sebeple asma tavan sistemlerinin deprem boyunca performansı, binanın kullanım amacına bağlı olarak kritik bir önem taşımaktadır (Sarıdoğan, 2013, s.1).

\subsection{4 Çevresel Faktörler}

Yapı malzemelerin tamamında olduğu gibi bitiş yüzeylerinden biri olan asma tavanlarda da sürdürülebilirlik, geri kazanım, zehirli gazlar, tehlikeli madde salınımı son derece önemlidir. Asma tavanlar iç mekanda yüzey olarak oldukça büyük bir hacim kaplayabilmektedirler. Bu yüzeylerde kullanılan asma tavan bileşenlerinin sağlığa zararlı olması, zehirli gaz çıkarmaması ve tehlikeli madde içermemesi beklenmektedir. Asma tavanlarda kullanılan bileşenlerin zararlı mikroorganizma üremesine yatkınlık açısından da değerlendirilmesi beklenmektedir. Özellikle tavanın hiçbir kısmında asbest açığa çıkmaması ya da içermemesi, formaldehit içeren malzeme kullanılması 
durumunda dikkatli olunması, standartlara uygun davranılması gerekmektedir (TS EN 13964, 2014, s.30).

\section{Asma Tavan Çeşitleri, Bileşenleri ve Taşıyıcı Sistemleri}

Asma tavan sistemleri uygulanmaları yönünden genelde ikiye ayrılır:

- Hazır Asma Tavan Malzemesiyle Oluşturulan Asma Tavanlar

- Yerinde oluşturulan Asma Tavanlar

$\mathrm{Bu}$ iki uygulama dışında, her iki uygulamanın bazı özelliklerine sahip asma tavanlar, karma asma tavanlar diye adlandırılabilir (TS EN 13964, 2014, s.4).

Bu makale kapsamında hazır asma tavan malzemesiyle oluşturulan asma tavanlar incelenmiştir. Hazır asma tavan malzemesiyle oluşturulan asma tavanlar, asma tavan taşıyıcı sistemi ve asma tavan malzemesi olarak iki ana bileşenden oluşmaktadır (Şekil 1). Asma tavanı oluşturan bir diğer öğe asma tavan taşıyıcı sistemidir. Asma tavan taşıyıcı sistemleri de kendi içinde doğrudan taşıyıcı sisteme oturan sistemler ve askı çubuğu ile asılan sistemler olmak üzere iki farklı şekilde sınıflandırılabilir.

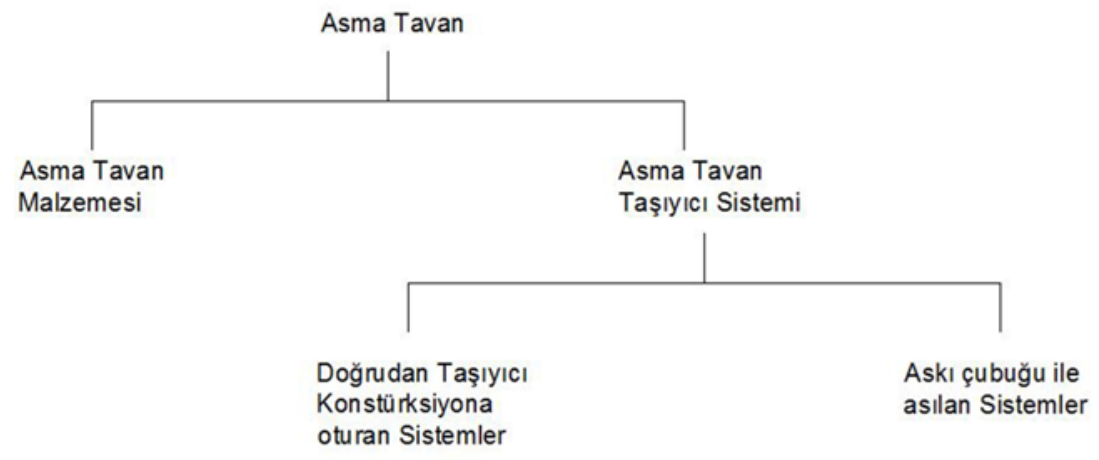

Şekil 1: Asma Tavan Bileşenlerinin Şematik Gösterimi (Yazar)

\subsection{Asma Tavan Çeşitleri}

\subsubsection{Doğrudan Taşıyıcı Konstrüksiyona Oturan Sistemler}

Asma tavan malzemesi, doğrudan tavan yüzeyine oturan sistemlerde metal ya da ahşap karkasın altına direkt olarak sabitlenir. Tavan kaplamalarında alt konstrüksiyon tavan kaplamasının taşıyıcı bölümüdür. Üstünkörü ve yetersiz uygulanan alt konstrüksiyon, tavan kaplamalarının sağlam ve düzenli olmasına engel teşkil etmektedir. Yeterli sağlamlıkta olmayan ve tavana sağlam tutturulmayan bileşenler yüzünden tavan yıkılabilir. Bu nedenle alt konstrüksiyon malzemelerinin tavana sağlamca tutturulmasına ve sağlamlığına dikkat edilmelidir. Alt konstrüksiyon metal (çelik gibi) veya ahşap karkastan yapılabilir. Alt konstrüksiyonu oluşturan bileşenlerin boyutları ve şekilleri taşıyacakları yüklere göre hesaplanır. Bileşenleri birbirine bağlayan geçme, kaynak, vidalama, çivileme gibi montaj yöntemlerine yeterli özen gösterilmelidir. Alt konstrüksiyon yapımın da ahşap karkas kullanılacaksa ağaç ikinci sınıf keresteden daha kötü kalitede olmamalıdır. Reçineli ve budaklı ağaç kullanılmamalı, ağacın nem derecesi \%8-12 dolaylarında olmalıdır. Yapının tavan yüzeyi düzgünse alt konstrüksiyon parçaları doğrudan tavana bağlanabilir, küçük yüzey bozuklukları küçük denkleştirme çıtalarıyla giderilebilir. Tavanı taşıyacak ahşap veya metal profillerin bağlantısını güçlendirmek için plastik veya metal dübeller kullanılabilir. 
Ahşap Karkas ile Oluşturulan Sistemler: Ahşap karkas ile oluşturulan sistemlerde ana taşıyıcı latalar (b), tavanın altına sistem sabitleyicilerle (a) monte edilir. Sonra ana taşıyıcı lataların altına, tali taşıyıcılar latalar (d) uygulanır. Tali taşıyıcıların alt kotunu da tavan kaplaması olarak seçilen asma tavan malzemesi kaplanır. Sabitleyiciler(a) arasındaki boşluk (x), ana taşıyıcılar arasındaki boşluk (y) ve tali taşıyıcılar arasındaki boşluk (L) üreticinin detaylarına göre değişiklik göstermektedir (Şekil 2).

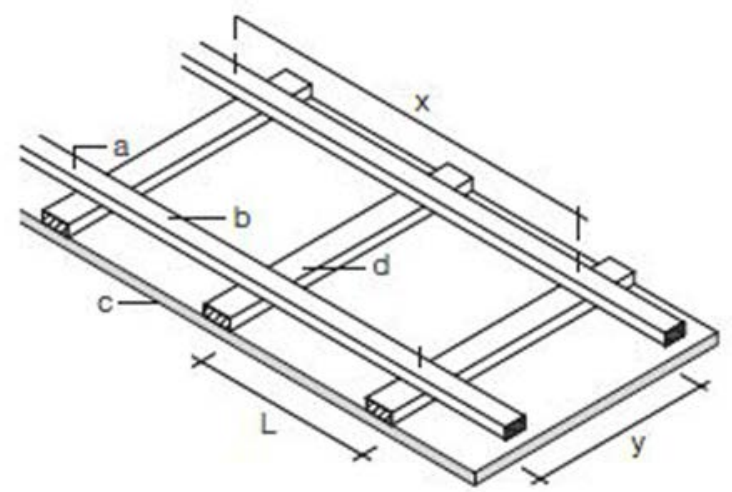

a -Tavanın altına sistemi sabitleyici

b -Ana taşıyıcı lata

c -Asma Tavan Kaplamas

d -Tali taşıyıcı lata

$x$-Sabitleyiciler arasındaki boşluk

y -Ana taşıyıcı latalar arasında boşluk

$\mathrm{L}$-Tali taşıyıcı latalar arasındaki boşluk

Şekil 2: Ahşap Karkas- Tavan Bağlantısı (Tichelmann ve Pfau, 2012, s.40)

Metal Karkas ile Oluşturulan Sistemler: Metal karkas ile oluşturulan asma tavanlarda tavanın altına sistem sabitleyiciler ile ana taşıyıcılar (b) takılır. Sonrasında bu ana taşıyıcılara (b), tali (yardımcı) taşıyıcılar monte edilir. Son olarak asma tavan malzemesi tali taşıyıcılara sabitleyiciler yardımıyla uygulanır. Sabitleyiciler (a) arasındaki boşluk $(\mathrm{x})$, ana taşıyıcılar arasındaki boşluk $(\mathrm{y})$ ve tali taşıyıcılar arasındaki boşluk (L) üreticinin detaylarına göre değişiklik göstermektedir (Şekil 3).

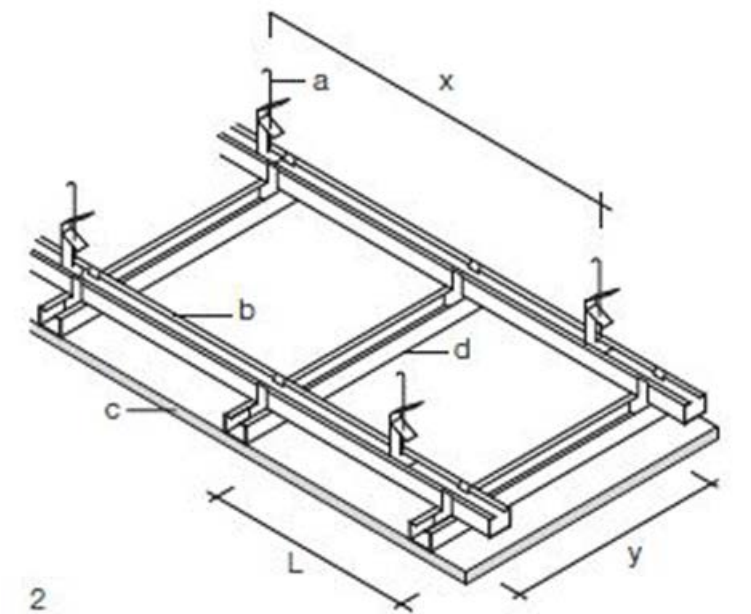

Şekil 3: Metal Karkas-Tavan Bağlantısı (Tichelmann ve Pfau, 2012, s.40) a -Tavanın altına sistemi sabitleyici

b -Ana taşıyıcı

c -Asma Tavan Kaplaması

d -Tali taşıyıcı

$x$-Sabitleyiciler arasındaki boşluk

y -Ana taşıyıcılar arasındaki boşluk

L - Tali taşıyıcılar arasındaki boşluk

\subsubsection{Askı Çubuğu ile Asılan Sistemler}

Askı çubuğu ile asılan asma tavan sistemlerinde, tavan malzemesi, metal ya da ahşap karkas altına kancalarla asılmaktadır. Askı çubuğu ile asılan sistemler; sabitleyiciler, kanca, askılar, taşıyıcı profiller, bağlayıcılar ve tavan malzemesinden oluşmaktadır. Askı ile asılan sistemlerde, yük taşıyan döşemeye (b), tavan altına sabitleyici (a) monte edilmektedir. Sonraki aşamada, askı sistemine ana taşıyıcılar ana taşıyıcılara tali taşıyıcıların bağlantısı yapılmaktadır. Son olarak asma tavan malzemesi uygulanmaktadır (Şekil 4). 


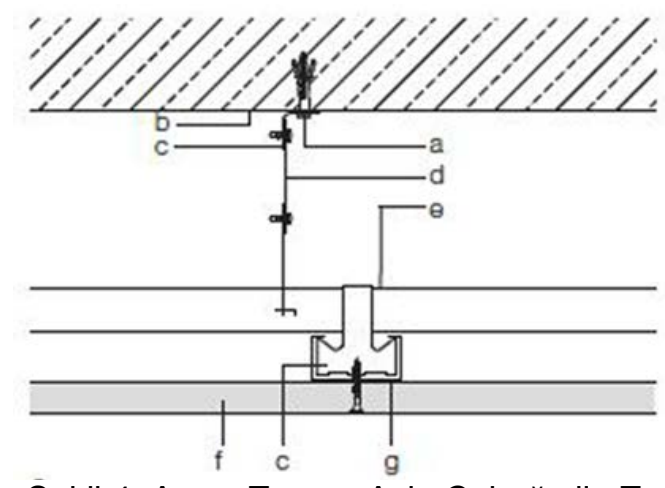

a -Sabitleyiciler

b -Yük Taşıyan malzeme

c -Bağlayıcı

d -Askı

e -Ana taşıyıcı

f -Tavan malzemesi

g -Tali taşıyıcı

Şekil 4: Asma Tavan- Askı Çubuğu ile Tavan Bağlantısı (Tichelmann ve Pfau, 2012, s.40)

\subsection{Asma Tavan Bileşenleri}

Asma tavan uygulama yöntemleri, 'EU Construction Products Directive', TC. Çevre ve Şehircilik Bakanlığı tarafından 'Yapı Malzemeleri Yönetmeliği' adı altında yayımlanmıştır. Asma tavanların yapıya monte edilebilmeleri için birbiriyle birleştirilmesi gereken elemanlar vardır. Asma tavan taşıyıcı sistemi, bütünüyle bir bileşen takımından oluşabileceği gibi, tekil bileşenlerden de oluşturulabilir (Şekil 5). Asma Tavanı oluşturan malzemeler;

- Sabitleyiciler

- Askılar

- Bağlayıcılar

- Taşıyıcılar

- Tavan kaplamasından oluşmaktadır (TS EN 13964, 2014, s.9-13).

\subsubsection{Sabitleyiciler}

Sabitleyiciler, askı bileşenlerini veya asma tavan taşıyıcı sistemini yük taşıyıcı yapı elemanlarına bağlayan sabitleme elemanlarıdır. Sabitleyiciler; üst sabitleme elemanları ve çevre sabitleme elemanlarından oluşmaktadır. Üst sabitleme elemanı, asma tavan taşıyıcı sistemini veya askı bileşenlerini doğrudan yük taşıyıcı yapı elemanına bağlayan sabitleme elemanıdır. Tavan çevre profili sabitleme elemanı ise, tavan çevre profilini doğrudan yük taşıyıcı yapı elemanına bağlamaktadır. Kenar profili ya da köşebent olarak da isimlendirilen bu eleman, ana ve tali taşıyıcı profillerin duvar kısmında bulunan bitiş noktalarının oturtulmasıyla bir çeşit mesnet görevinde kullanılan asma tavan elemanıdır (TS EN 13964, 2014, s. 10).

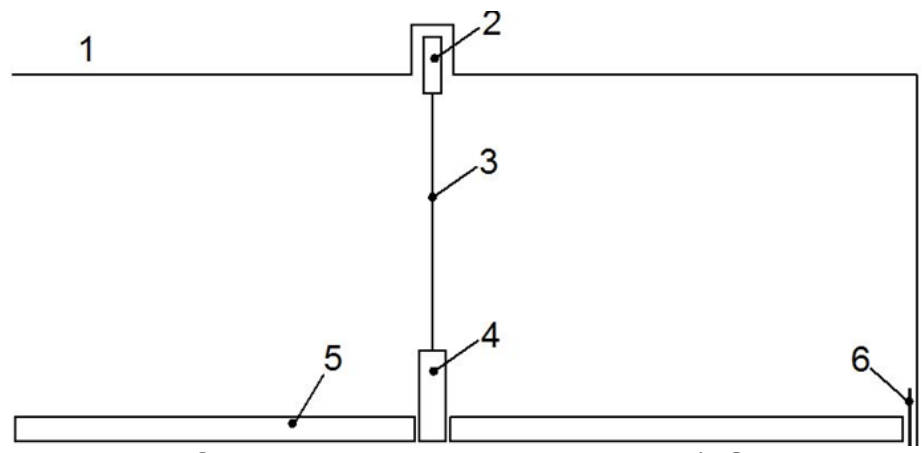

1- Yük taşıyıcı yapı elemanı (betonarme, çelik kiriş vb.) 2- Üst sabitleme elemanı (tij dübeli, çelik dübel vb.)

3- Askı bileşeni (tij, askı teli vb.)

4- Mesnet elemanı ( ana taşıyıcı konstrüksiyon vb.) 5- Asma tavan çevre profili (tali taşıyıcı )

6- Tamamlayıcı eleman ( Şekil 5: Asma Tavan Bileşenleri (TS EN 13964, 2014, s. 9).

\subsubsection{Askı Elemanları}

Askı elemanları, asma tavan taşıyıcı sisteminin bir bölümünü oluşturan ve bu sistemi yük taşıyıcı yapı elemanına bağlayan bileşenlerdir. Bu bileşen, bir bileşen takımının veya monte edilmiş asma tavan sisteminin bir bölümü olabilir (TS EN 13964, 2014, s. 
10). Askı elemanları üretici firmaların tasarımına göre şekil, ölçü ve işlevsellik açısından farklılık göstermektedir. Tavanda kullanılacak askı takımlarının korozyona karşı direnç göstermesi beklenmektedir.

\subsubsection{Bağlantı Malzemeleri}

Çiftli yay, klips, ekleme parçası gibi elemanları birbirine bağlantısını sağlayan yardımcı elemanlardır. İki askı telini, ana taşıyıcı ve tali taşıyıcıyı birbirine bağlayan ya da profillerin ek yerlerine uygulanarak profil boyunun sürekliliğini sağlayan galvanize çelik profillerdir (TS EN 13964, 2014, s. 10).

\subsubsection{Taşıyıcılar}

Asma tavan bileşenlerinden biri olan taşıyıcılar asma tavanı oluşturan en önemli elemanlardandır. Asma tavan taşıyıcı sistemleri taşıyıcı profiller yardımıyla oluşturulur. Taşıyıcı profiller, asma tavan taşıyıcı sisteminin askı bileşeni veya doğrudan sabitlenmiş bileşen ile bağlantılı askı bileşenidir (TS EN 13964, 2014, s. 9-10).

\subsubsection{Tavan kaplaması}

Asma tavan sisteminin en önemli bileşenlerden biri tavan kaplamasıdır. Tavanda istenen performansların büyük kısmı tavanda kullanılan tavan kaplama malzemesinin özellikleri sayesinde karşılanır. Asma Tavanlarla ilgili standart olan TS EN 13964'te tavan kaplama bileşeni asma tavan kaplamasının bir bölümünü oluşturan mamul (karo veya kaplama tahtası görünümlü olan, vb.) olarak tanımlanmıştır (TS EN 13964, 2014, s. 10-11). Asma tavan kaplama bileşeni herhangi bir biçimde olabileceği gibi (masif, boşluklu, oluklu, ızgara vb.), asma tavan kaplaması olarak farklı kökenli malzemeler kullanılabilir.

Şekil ve Kenar Tiplerine Göre Kaplama Malzemeleri: Tavan kaplama malzeme şekilleri TS EN 13964 (2014, s. 9-13) standardında temel olarak; hacimli asma tavan kaplama bileşeni, ince asma tavan kaplama bileşeni, karo görünümlü kaplama bileşeni ve doğrusal asma tavan kaplama bileşeni olarak gruplandırımıştır. Bu kaplama bileşenleri farklı kenar tiplerinde olabilmektedir. Bu bileşenlerden hacimli asma tavan kaplama bileşeni, kenarları, malzeme kalınlığı boyunca şekillendirilmiş olan kaplama bileşenidir. Ince asma tavan kaplama bileşeni ise kenarları, ana levha malzemenin şekillendirilmesiyle oluşturulan ve kalınlığı, kalıcı şekillendirmeye imkân veren kaplama bileşenidir. Karo görünümlü asma tavan kaplama bileşeni, uzunluk (I)/genişlik (w) oranı $1 \leq \mathrm{I} / \mathrm{w} \leq 2$ aralığında olan, kare veya dikdörtgen şekilli kaplama bileşenleridir. Kaplama tahtası görünümlü asma tavan kaplama bileşeni uzunluk (I)/genişlik (w) oranı $2 \leq \mathrm{I} / \mathrm{w} \leq$ $\mathrm{n}$ aralığında olan, dikdörtgen şekilli kaplama bileşenleridir. Doğrusal asma tavan kaplama bileşeni ise genişliği (w), uzunluğuna (I) kıyasla oldukça küçük olan kaplama bileşenleridir.

Malzeme Özelliğine Göre Tavan Kaplama Malzemeleri: Asma Tavan Sistemi bileşenlerinden biri olan asma tavan malzemesi, birçok farklı hammadde, özellik (renk, doku, kalınlık gibi) ve farklı biçimde tasarlanabilir. Genel olarak asma tavanlarda kaplama olarak kullanılan malzemeler çok çeşitli olup, en yaygın kullanılanları alçı pano, sıva, çeşitli özel paneller ve yanıcı olmayan liflerden üretilmiş karolardır (Allen ve Iano, 2009, s. 925). Aşağıdaki şekilde gruplanabilmektedir;

- Alçı ve Alçı Kökenli Asma Tavan Kaplama Malzemeleri
a. Alçı Döküm Tavan
b. Kartonlu Alçı Levha
c. Akustik Alçı Levha
d. Hazır Alçı Plakalar 
- Metal ve Metal Kökenli Asma Tavan Kaplama Malzemeleri Alüminyum, Galvanize ve Paslanmaz Çelik

Levha, Izgara ya da lamel

- Ahşap Kökenli (organik) Asma Tavan Kaplama Malzemeleri

a. Masif levhalar

b. Ahşap lif levhalar (MDF, MDFlam)

c. Ahşap yonga levhalar (Sunta, Suntalam)

d. Ahşap talaş levha

- Mineral Kökenli(inorganik) Asma Tavan Kaplama Malzemeleri

a.Taş Yünü

b. Cam yünü

- Polimer Kökenli Asma Tavan Kaplama Malzemeleri

a. Pleksiglas

b. Gergi Tavan

- Kumaş Asma Tavan Kaplama Malzemeleri

- Seramik Asma Tavan Kaplama Malzemeleri

- Cam Asma Tavan Kaplama Malzemeleri

\subsection{Asma Tavanlarda Taşıyıcı Sistemler}

Asma tavan kaplama malzemelerini taşıyan asma çerçevedir. Bu sistem, bütünüyle bir bileşen takımından oluşabileceği gibi, tekil bileşenlerden de oluşabilir. Asma tavan malzemesini taşıyarak yükün döşemeye aktarılmasını sağlar. Kullanıcı tarafından tavan arkasına müdahale edilip edilmemesine göre iki farklı sistemde tanımlama yapılabilir.

\subsubsection{Monoblok Taşıyıcı Sistemler (vidalı sistemler)}

Monoblok taşıyıcı sistemlerde, asma tavan kaplama malzemeleri sabit vidalı sistemlerle taşıyıcı profillere monte edilmektedir. Tavan kaplamaları taşıyıcı profillere vidalanmaktadır (Şekil 6). Kaplama malzemesinin üzerine boya ve farklı uygulamaların yapıldığı sıklıkla görülmektedir. Alçı gibi malzemelerin uygulamalarında plakaların birleşimlerinde derz dolgusu alçısı ve derz bandı kullanılmaktadır. Tavan yüzeyine bakıldığında, tavanda sürekliliğin olduğu, kesintisiz, hiçbir derzin olmadığı sistemlerdir. Asma tavanın arkasına sık müdahale edilmesi gerekmeyen alanlarda daha çok tercih edilmelidir.
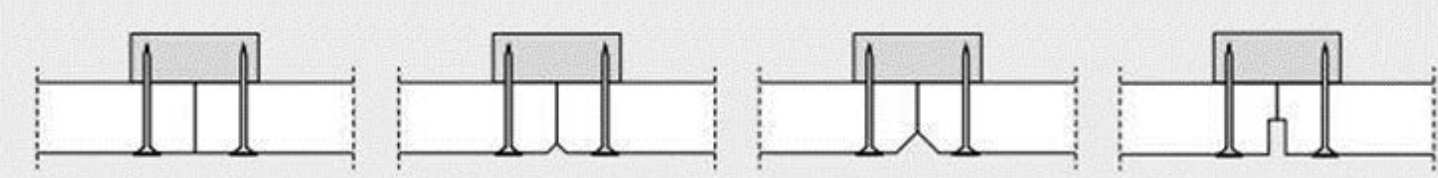

Şekil 6: Monoblok Sistemlerde Plaka Birleşim Gösterimleri (URL 1)

\subsubsection{Modüler Taşıyıcı Sistemler}

Modüler Taşıуıcı Sistemlerde tavan kaplama malzemeleri kullanıcı tarafından sökülüp takılabilir. Tavan kaplama malzemeleri modüller şeklinde taşıyıcı profillerle kullanılabilir. TS EN 13964 (2014, s. 13-16) 'e göre farklı tipte kenar yapılarına göre; görünür, yarı gizli ve gizli asma tavan taşıyıcı sistemi olarak yer almaktadır. Bunun dışında kaplama malzemesine göre de özel üretimler yapılabilmekte, projeye özgü çözümlenmiş ve detaylandırımış olarak da ele alınabilmektedir. 


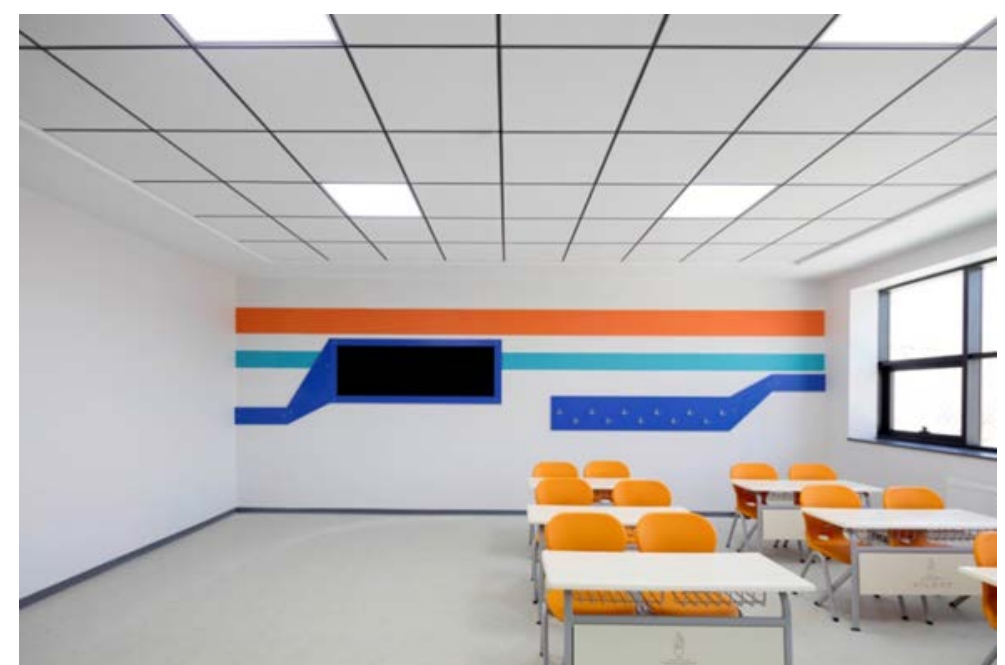

Fot. 2: T15-T24 Görünür Taşıyıcı Sistem Örnek Fotoğrafı (URL 1)

\subsubsection{Görünür Asma Tavan Taşıyıcı Sistemi}

Tavan yüzeyine bakıldığında; asma tavan taşıyıcı profilinin görüldüğü tavan sistemleridir. Tavan yüzeyinde kullanılan malzemenin, taşıyıcı profile monte detayına göre, sarkmalı veya hem yüz olarak tanımlanabilir. Bu sistemlerde genel olarak T15, T24 ve kanallı taşıyıcılar kullanılmaktadır (Fot. 2). Görünürlüğünün farklı olması açısından aşağıdaki gibi gruplandırılmıştır.

- Sarkmalı görünür asma sistemi

- Oturtmalı görünür asma sistemi

- Fugalı görünür asma tavan sistemi

Sarkmalı Görünür Asma Tavan Sistemi: Tavan malzemesinin taşıyıcıdan sarktığı sistemlerdir. Farklı sarkma miktarları da mevcuttur (8, 12, $15 \mathrm{~mm}$ gibi). Plaka kenar detayına göre değişiklik gösterebilir (pahlı, küt, pluto kenar gibi). Kenar detayı aşağıdaki gibidir. Plaka Kenar Detayı: T15 ya da T24 taşıyıcıya kenarındaki tırnaklara oturur (Şekil 7).

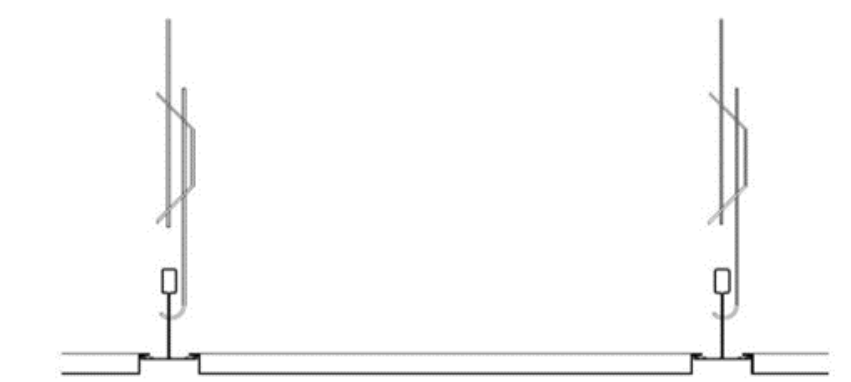

Şekil 7: Sarkmalı Plaka-Plaka Birleşim Örnek Kesiti (URL 1)

Oturtmalı Görünür Asma Tavan Sistemi: Plaka alt kotuyla, taşıyıcı alt kotunun aynı seviyede olduğu sistemlerdir. Plakanın taşıyıcının kulaklarına serbest olarak bırakıldığı sistemdir. Plaka Kenar Detayı: T15 ya da T24 taşıyıcının üzerine oturur (Şekil 8). 


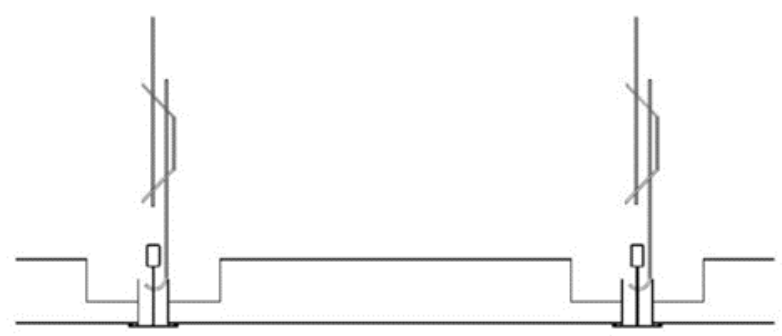

Şekil 8: Oturtmalı Plaka-Plaka Birleşim Örnek Kesiti (URL 1)

Fugalı Görünür Asma Tavan Sistemi: Plaka alt kotuyla, taşıyıcı alt kotunun aynı seviyede olduğu, Plaka taşıyıcının kulaklarına serbest olarak bırakıldığı sistemdir. Taşıyıcı profilin kesiti sayesinde tavan yüzeyinde taşıyıcılar fugalı olarak görülmektedir. Plaka kenar detayı: Kanallı taşıyıcının kenarındaki tırnaklara oturur (Şekil 9).

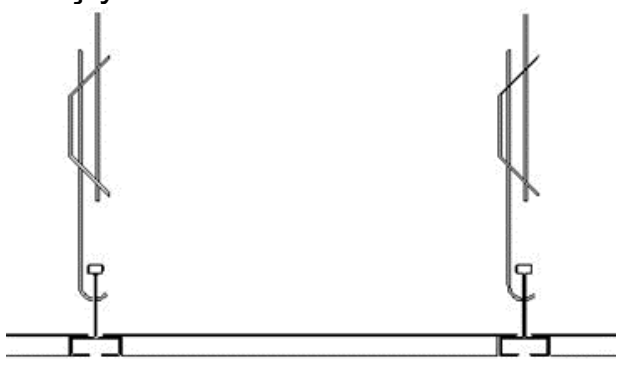

Şekil 9: Kanallı Taşıyıcılı Plaka-Plaka Birleşim Örnek Kesiti (URL 1)

\subsubsection{Gizli Asma Tavan Taşıyıcı Sistemleri}

Asma tavan yüzeyine bakıldığında, sistemi taşıyan taşıyıcı profillerin görülmediği, geçmeli ve kancalı taşıyıcı sistem çeşitlerinin olduğu sistemlerdir. Panel birleşimlerinde minimum derz olması sayesinde tavanda kesintisiz bir görüntü oluşturmaktadır.

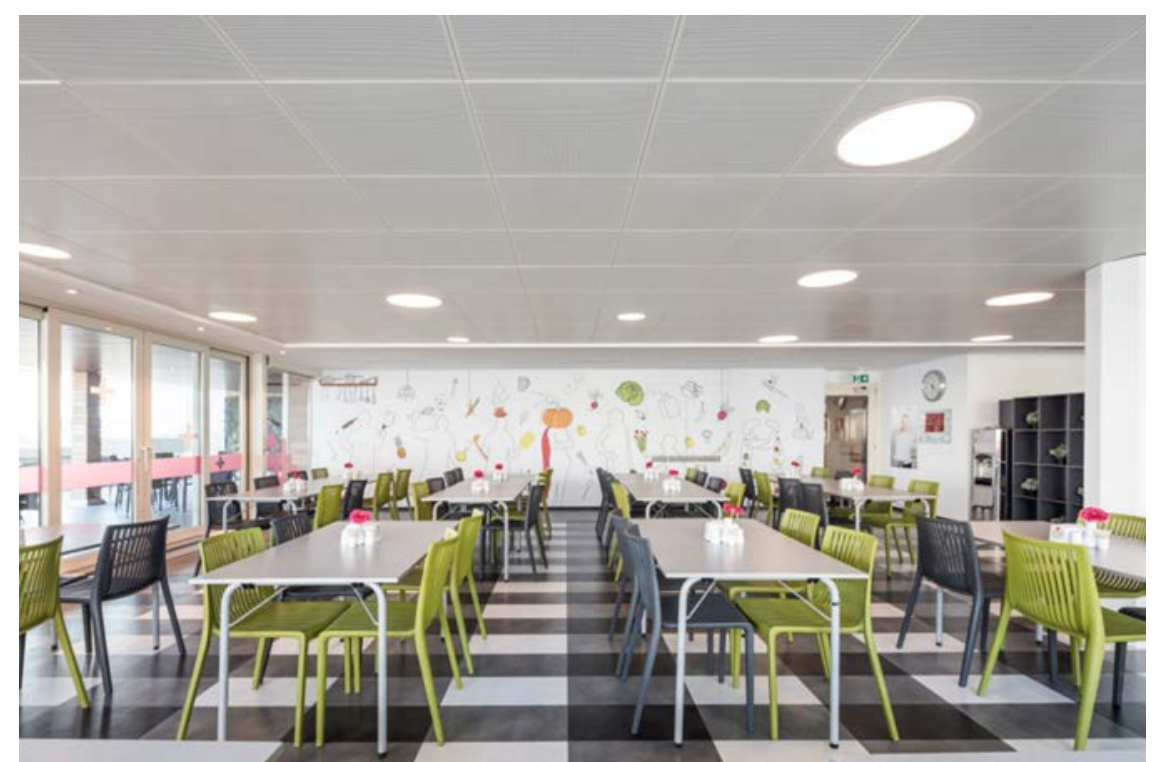

Fot. 3: Gizli Taşıyıcılı Geçmeli Asma Tavan Sistem Örnek Fotoğrafı (URL 1)

Gizli Geçmeli (Clip-in) Taşıyıcı Sistem: Gizli tipte asma tavan taşıyıcı sistemi üzerine geçmeli şekilde mesnetlenen, kaplama bileşeninin kenar yapısı oluklu ve yuvalı olan sistemlerdir (Fot. 3). Kenar Detayı: Kaplama malzeme bileşenin kenarı oluklu ve yuvalı, küt veya pahlı olarak bitebilir. (Şekil 10) 

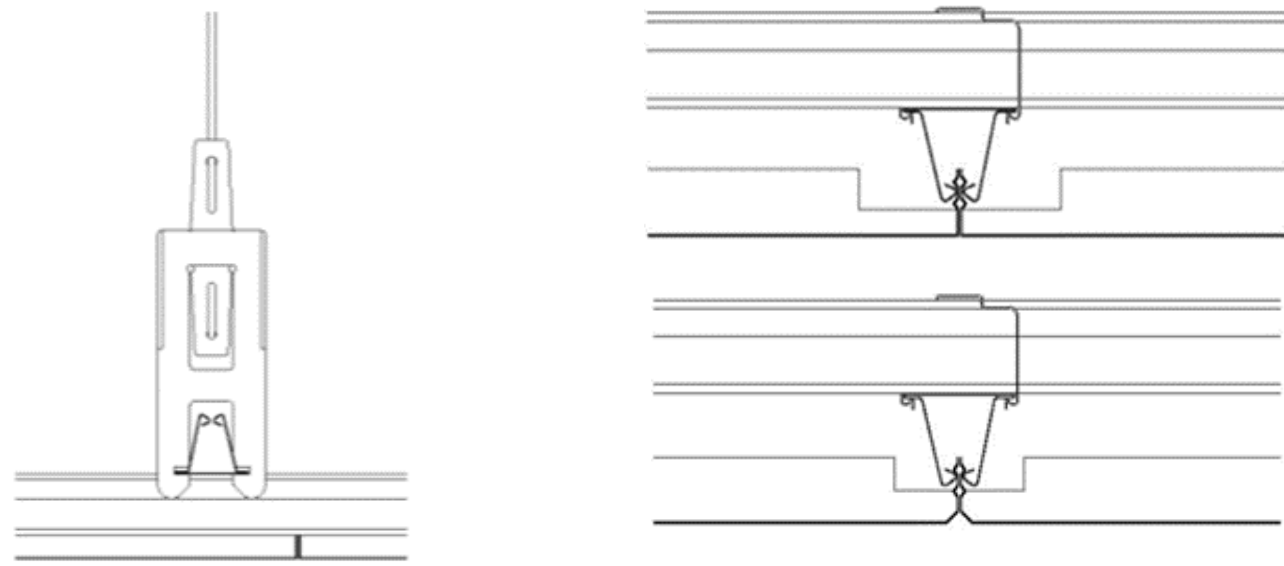

Şekil 10: Gizli Geçmeli Sistem Panel Birleşim Detayı (URL 1)

Gizli Kancalı (Hook-on) Taşıyıcı Sistem: Gizli tipte asma tavan taşıyıcı sistemi üzerine plakaların kenar bükümlerinden L profillere asılan kancalı bir taşıyıcı sistemdir (Fot. 4). Plaka kenar detayı bükümlü veya üst üste binerek taşıtılabilmektedir (Şekil 11).

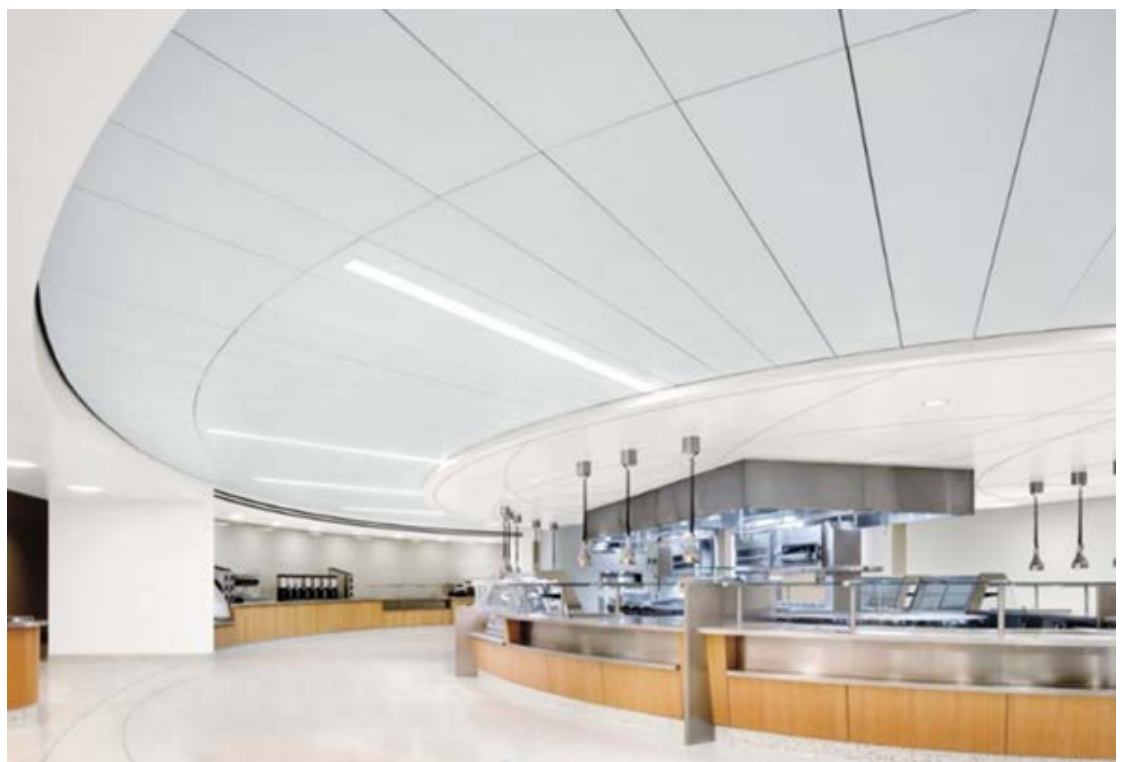

Fot. 4: Kancalı Taşıyıcılı Asma Tavan Sistem Örnek Fotoğrafı (URL 1)
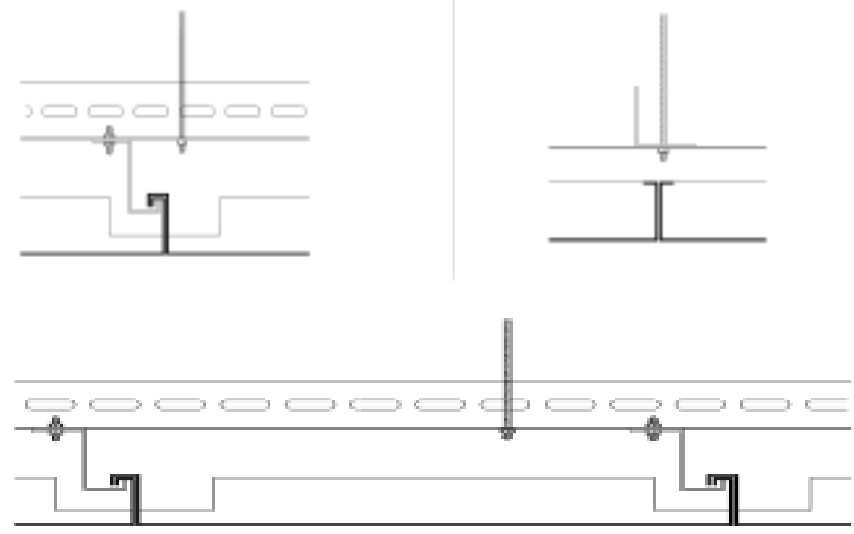

Şekil 11: Gizli Sistem Kancalı Panel-Panel Birleşim Örnek Kesiti (URL 1) 


\subsubsection{Yarı Gizli Asma Tavan Taşıyıcı Sistemleri}

Tavana bakıldığında, alt yüzeyinde sadece tek bir yönde taşıyıcıların görüldüğü sistemlerdir. Ana taşıyıcının görüldüğü, tali taşıyıcıların gizli olduğu sistemlerdir. Diğer taşıyıcı sistemler karma olarak kullanılabilir (Fot. 5). Plaka kenar detayında taşıyıcı sistem fuga şeklinde yarı görünür şekildedir (Şekil 12).
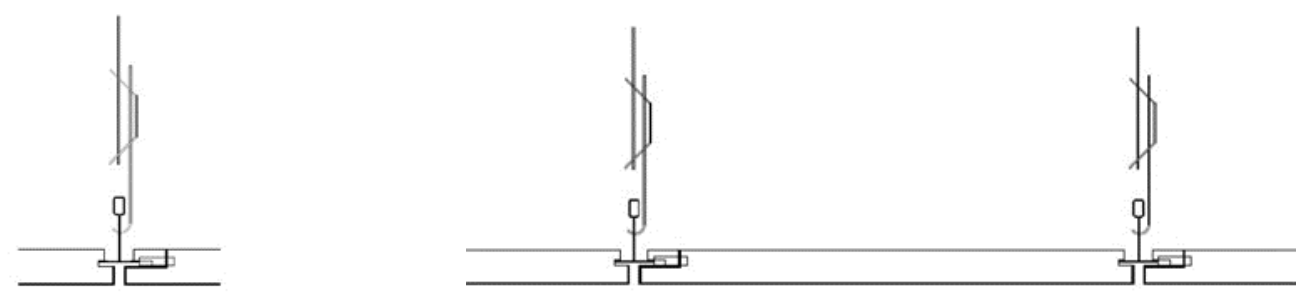

Şekil 12: Yarı Gizli Sistem Panel- Panel Birleşim Örnek Kesiti (URL 1)

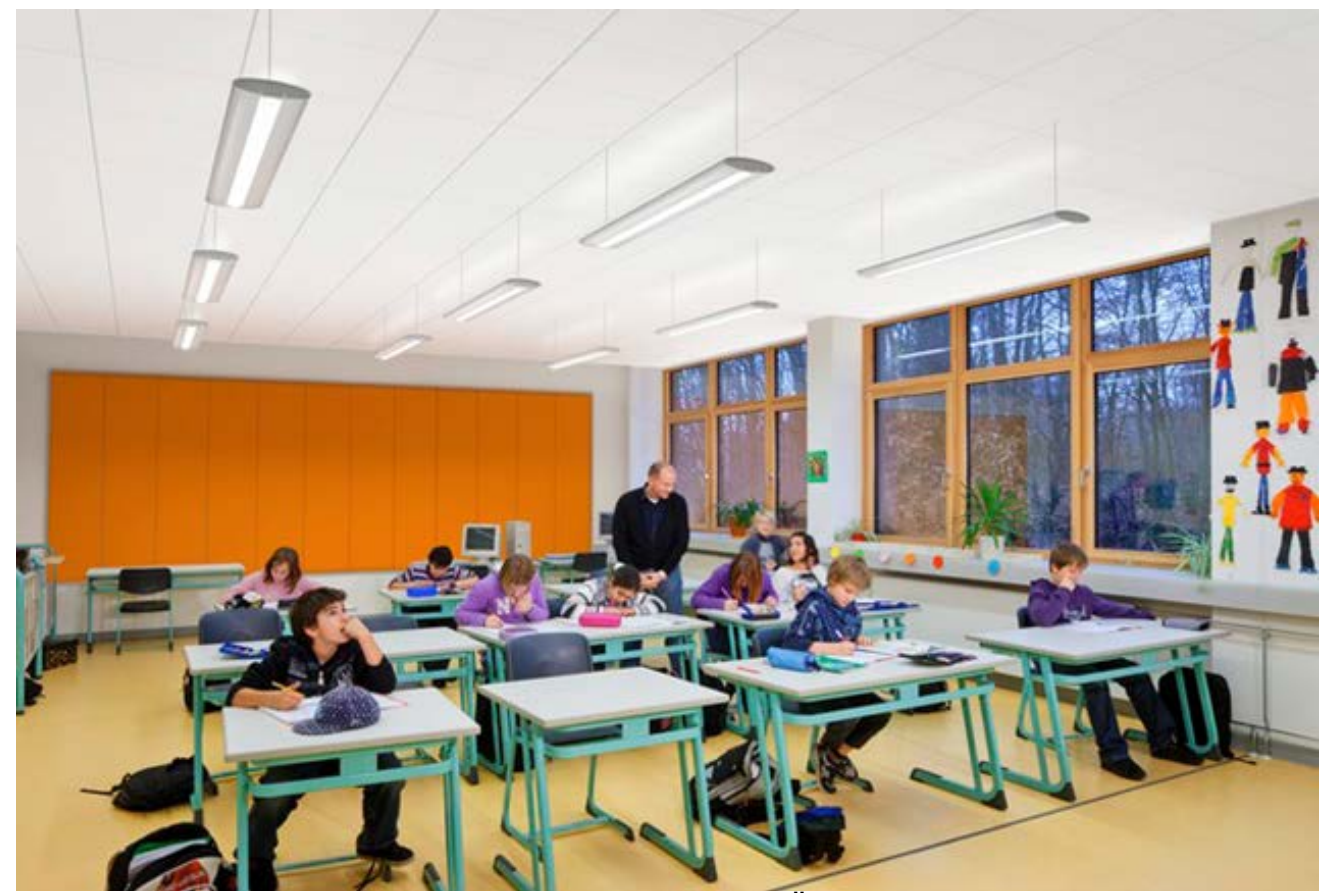

Fot. 5: Yarı Gizli Taşıyıcılı Asma Tavan Örnek Fotoğrafı (URL 1)

\subsubsection{Diğer asma tavan taşıyıcı sistem çözümleri}

Kaplama bileşenine göre taşıyıcısının şekillendirildiği asma tavan sistemleridir. İstenildiği zaman kullanıcı tarafından sökülüp takılabilmektedir. Bu çalışmada doğrusal asma tavan kaplama bileşenine göre, düşey asma tavan kaplama bileşenine göre ve ızgara asma tavan bileşenine göre asma tavan taşıyıcı profilleri kısaca anlatılmıştır. Kaplama bileşenine göre farklı taşıyıcı profillerde uygulanabilmektedir.

Doğrusal Asma Tavan Sistemi: Doğrusal tavan kaplama bileşenlerinin asma tavan taşıyıcı sistemine mesnetlenmesiyle yapılan asma tavan sistemleridir (Şekil 13). Farklı tasarımlar mümkün olabilmektedir. Özel taşıyıcı sistem profilleri kullanılmaktadır. 


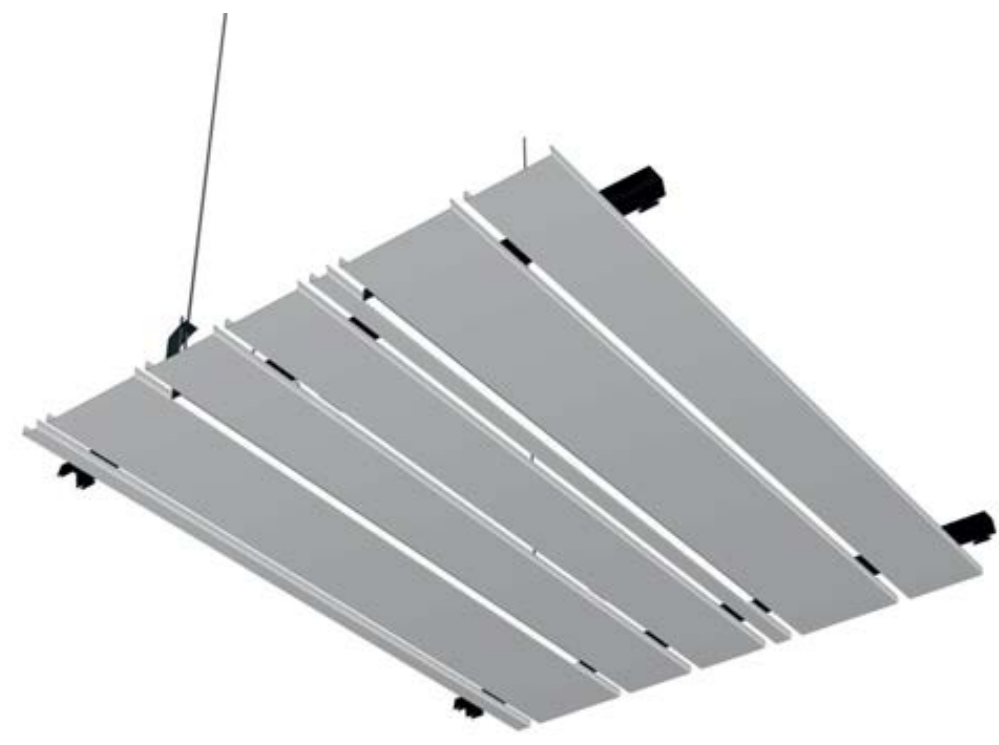

Şekil 13: Doğrusal Asma Tavan Plaka-Taşıyıcı Örnek Gösterim (URL 1)

Bölmeli Asma Tavan Sistemi: Düşey tavan kaplama bileşenlerinin, birbirlerine belirli mesafede monte edilmesiyle yapılan asma tavanlardır. Farklı tasarımlarda mevcut olabilir (Şekil 14).

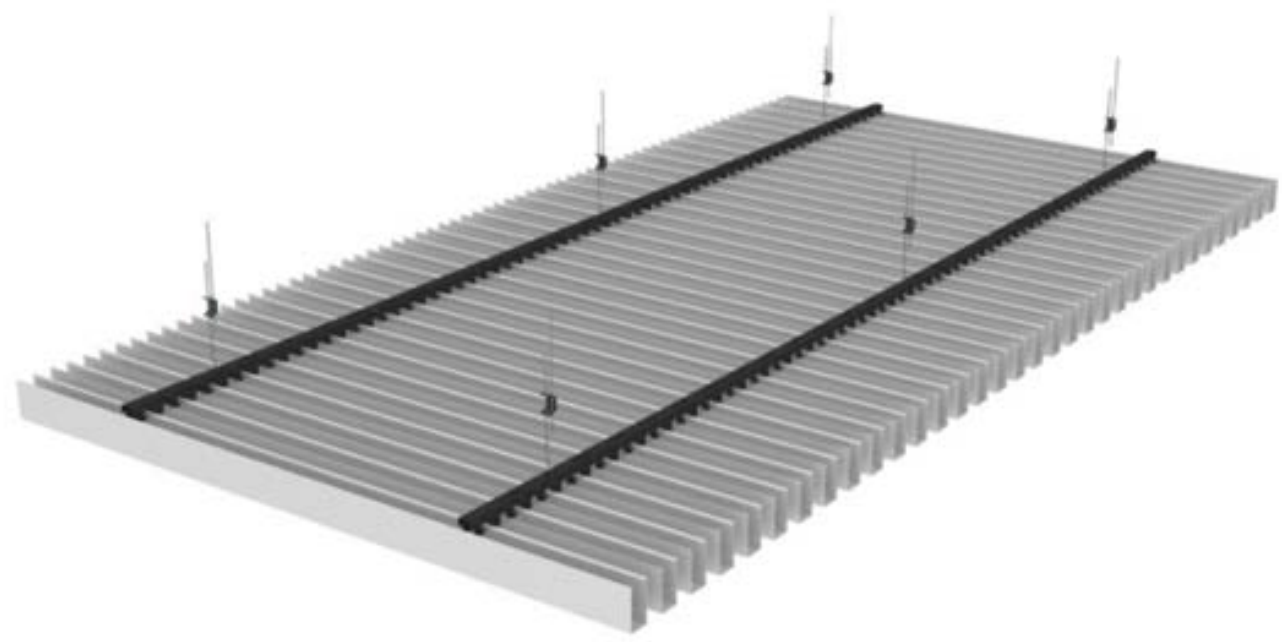

Şekil 14: Bölmeli Asma Tavan Plaka -Taşıyıcı Örnek Gösterim (URL 1)

Izgara Asma Tavan Sistemi: Izgara şeklindeki tavan kaplama bileşenlerinin birbirlerine belirli mesafede monte edilmesiyle yapılan asma tavanlardır. Farklı tasarımlarda söz konusu olabilmektedir (Şekil 15). 


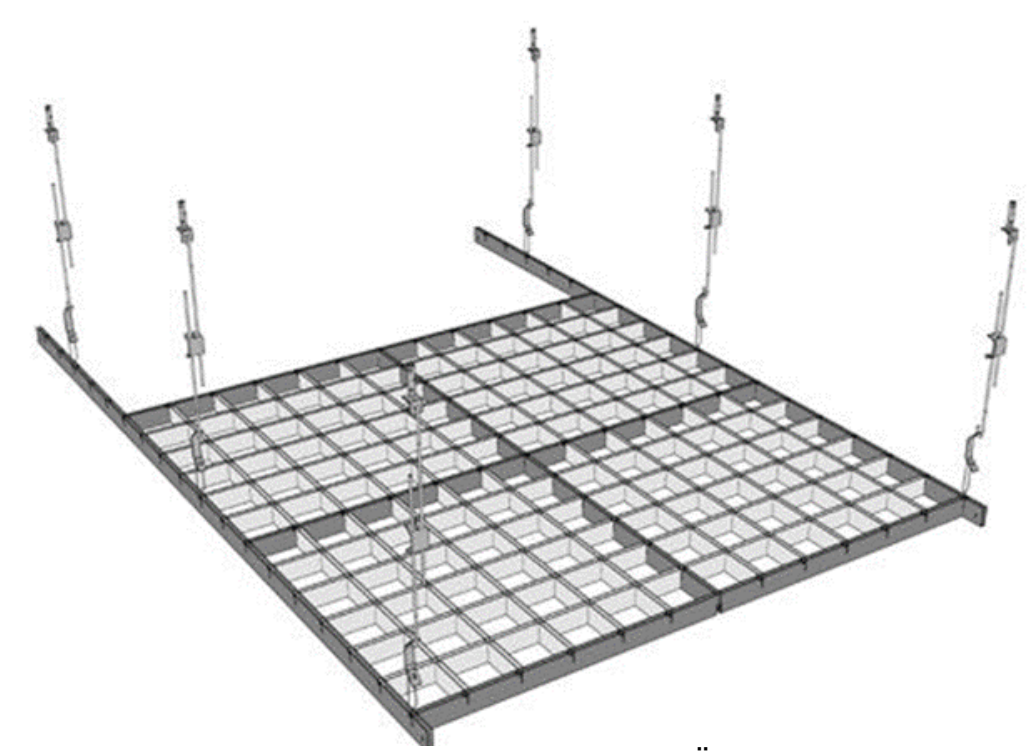

Şekil 15: Izgara Asma Tavan Plaka -Taşıyıcı Örnek Gösterim (URL 1)

\subsection{Asma Tavan Uygulamaları}

Ülkemizde asma tavan sistemleri ile ilgili TS EN 13964 standardı bulunmaktadır. TS EN 13964 standardı, asma tavan sistemlerinin binalar ve inşaat mühendisliği alanına giren diğer yapıların iç mekânlarında kullanılan asma tavan sistemlerinin tasarımı, imalatı ve seçiminden sorumlu ilgili taraflara yönelik gerekli bilgileri, bileşen takımı hâlinde satılan asma tavan taşıyıcı sistemlerini, bu taşıyıcı sistemlere ait tekil bileşenleri ve asma tavan kaplama bileşenlerini, karşılaması gereken gereksinimleri (modüler boyut, taşıyıcı sistem mekanik direnci, akustik, yangın, dayanıklılık, ısı yalıtımı vs.) ve bu gereksinimler ile ilgili deney yöntemlerini (çekme, eğilme, rüzgar yükü, darbe vs.) kapsamaktadır (TS EN 13964, 2014, s. 37-45). Ancak bu standartta asma tavanların montaj koşullarını tanımlayan herhangi bir madde bulunmamaktadır. TS EN 13964'e göre bu sistemlerin montajı tedarikçi firmanın talimatlarına göre yapılmaktadır. Ancak bu madde uygulamalarda farklılıklara yol açmakta ve çeşitli sorunlara yol açmaktadır. Fakat yurtdışındaki standartlar incelendiğinde farklı durumlarla karşılaşılmaktadır. Örneğin Amerika'da asma tavan sistemlerinin montajı yürürlükte bulunan ASTM E580'de tanımlanan asgari koşulları sağlayacak şekilde yapılmaktadır (Sarıdoğan, 2013, s.1). Çalışmanın bu bölümünde, asma tavan uygulamaları asgari gereklilikler niteliğinde genel kullanımları ele alınarak incelenmiştir.

\subsubsection{Asma Tavan Malzemesinin Doğrudan Tavana Uygulanması}

Asma tavan malzemesinin tavana tespiti için önce $60-80 \mathrm{~cm}$ aralıklarla yaklaşık $3 \times 5 \mathrm{~cm}$ boyutunda ahşap ya da metal latalar alt yüzeyleri terazide olacak şekilde tavana;

a. özel çivi tabancasıyla betona çivilenme yoluyla,

b. tavana matkapla açılmış deliğe yerleştirilen dübellere vidalanma suretiyle,

c. tavan kaplaması yapılacağının önceden tasarlanması sonucu, betonarme kalıbının üzerine yerleştirilen konik ahşap takozlara vidalanarak tespit edilmektedir.

Tavan yüzeyinin terazi de olmaması halinde birinci sıra latalarla tavanın teraziye getirilmesi (tam yatay olması) oldukça zor olduğundan önceden tespit edilmiş latalara dik doğrultuda ve aks ölçüleri asma tavan malzemesi levha boyutlarına uygun gelecek şekilde ikinci sıra latalar vidalanmaktadır. Böylece, tavan malzemesinin teraziye getirilmesi sağlanmış olmaktadır. Daha sonra asma tavan malzemesi bu ikinci latalara alttan uygun nitelikte ahşap vidalar ile tespit edilmektedir (Toydemir vd., 2000, s. 366). 


\subsubsection{Asma Tavan Malzemesinin Askı Sistemiyle Uygulanması}

$\mathrm{Bu}$ sistemde asma tavan taşıyıcılarının tavana asılması değişik askı elemanlarıyla yapılabilmektedir. Bunlardan en çok uygulananları sırasıyla; asma tavan askı çubuklarının tavana vidalanan halkalara takılarak tespitidir. Genelde bu yöntem artık pek uygulanmamakla birlikte, betonarme döşeme kalıbının yapımı sırasında betonarme demirlerine bağlanıp kalıba açılan deliklerden sarkıtılan ve sakal adı verilen çubuklara asma tavan askı çubuklarının bağlanması da uygulama yöntemlerinden biridir.

Diğer bir yöntemde asma tavan, çubuk ya da tellerinin tavana dübele tespit edilmiş bir köşebent yardımıyla bağlanmasıdır. Asma tavanın iki ayrı çubuk ve bir yaylı ayar mandalıyla tavana bağlanması ve asma tavanın tavana köşebent ya da lama yardımıyla ayarlı olarak asılmasıdır (Toydemir vd., 2000, s.366). Bu çalışma kapsamında asma tavan malzemesinin askı sistemiyle tavana uygulanması mono blok ve modüler tavan uygulamaları olmak üzere iki bölümde incelenmiştir.

\subsubsection{Monoblok tavan uygulamaları}

Monoblok asma tavan uygulamalarına ölçme ve işaretleme ile başlanır. Mimari projede oluşturulan asma tavan kesitine göre uygulama yapılacak tavan kotu hortum terazi veya lazer terazi ile işaretlenir. İşaretlenen tavan bitiş kotu diğer duvar yüzeyleri üzerine taşınarak çırpı ile işaretlenir. Askı elemanlarının yerleri, ilki duvardan $25 \mathrm{~cm}$ açıktan başlamak üzere, tavan sistemine ve yük sınıfına göre belirlenir. Köşe noktasına konulacak askı çubukları dik olarak duvarlara uzaklığı 100-150 mm olmalıdır. İkinci aşama konstrüksiyonun kurulmasıdır. Bu aşamada duvar yüzeyleri üzerine işaretlenen kot dikkate alınarak tavan $U$ profilinin alt hizası, çizginin üstüne gelecek şekilde dübel vida ile sabitlenir. Sabitlemenin en az $600 \mathrm{~mm}$ en fazla $1000 \mathrm{~mm}$ aralıklarla yapılması tavsiye edilir (Saint-Gobain Rigips, 2013, s.163).

Ana taşıyıcı profil yükünü tavana aktaracak olan askı elemanları önceden belirlenen yerlere (Askı çubukların taşıyacağı Ana Taşıyıcı Tavan C profillerin yerleşimi odanın ölçülerine göre planlanmalıdır. Bu plana göre askı çubuklarının yerleri hazırlanır, çelik dübelin L kıvrımına geçirilerek tavana sabitlenir (Şekil 16) (Saint-Gobain Rigips, 2013, s.163). Askı çubuklarının aralarında en fazla $900 \mathrm{~mm}$ olması tavsiye edilmektedir. Asma tavanlardan sismik bir beklenti olması durumunda, sismik çelik dübel kullanılmalıdır.

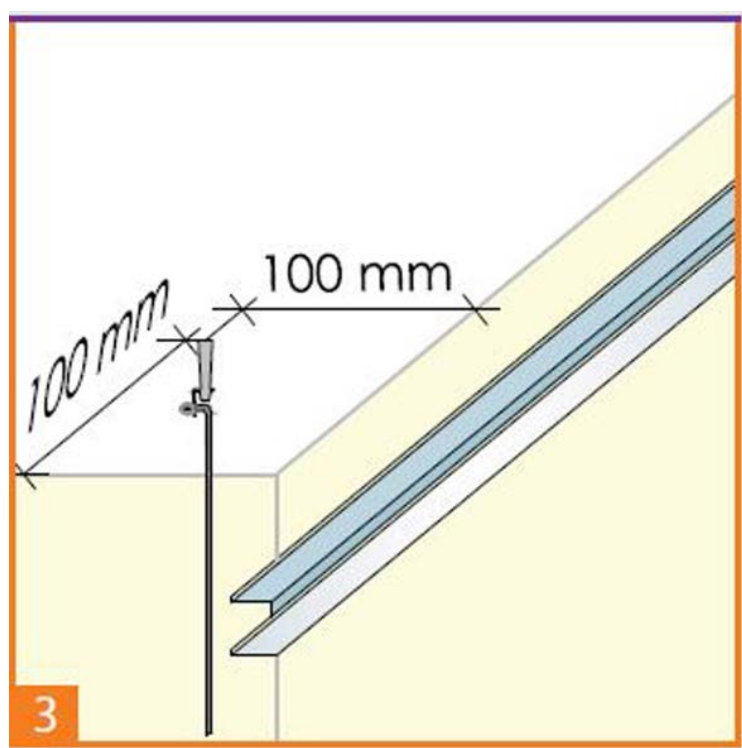

Şekil16: Tavan C Profillerin Sabitlenmesi (Saint-Gobain Rigips, 2013, s.163) 
Ana taşıyıcı tavan C profillerin ilki ile sonuncusu duvardan yaklaşık $15 \mathrm{~cm}$ mesafede olacak şekilde yerleştirilir. Aralarındaki mesafe asma tavan yük sınıfına göre belirlenir (Şekil 17) (Saint-Gobain Rigips, 2013, s.163). C profillerin aralarında en fazla $1100 \mathrm{~mm}$ olması tavsiye edilmektedir.

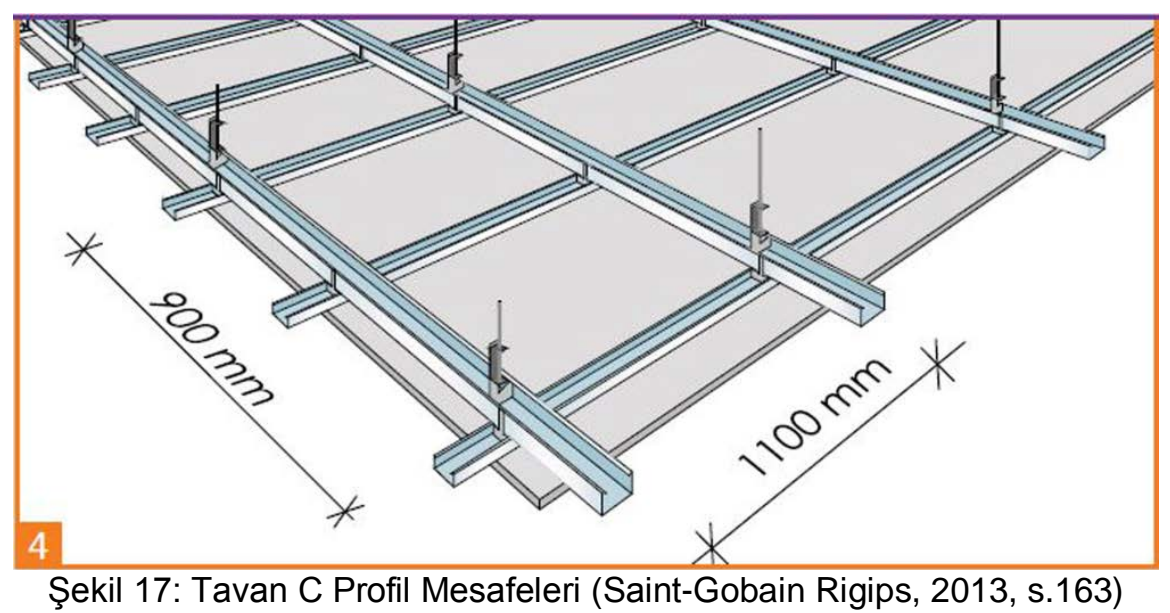

Tavan C profiller seçilen askı elemanlarına uygun askı maşaları ile tutturulmaktadır. Askı maşaları aynı yöne bakacak şekilde askı çubuklarına geçirilmektedir. Ana Taşıyıcı Tavan C profili, askı maşalarının tırnaklarına geçirilerek oturtulmaktadır. Askı maşaları sistemin kotunu ayarlamaya olanak verdiği için kontrol edilerek uygulamaya devam edilmelidir. Asma tavanlarda yangın dayanımı ya da sismik bir beklenti varsa, agraf ya da güçlendirilmiş askı sisteminin kullanılması gerekmektedir. Ana Taşıyıcı Tavan C profillerine dik olarak yerleştirilecek Tali Taşıyıcı Tavan $\mathrm{C}$ profillerin ilki ile sonuncusu duvardan yaklaşık $10 \mathrm{~cm}$ mesafede, en fazla 400-500 mm aks aralıklarında klips yardımı ile sabitlenmektedir (Şekil 18) (Saint-Gobain Rigips, 2013, s.164). Asma tavanlarda yangın dayanımı ya da sismik bir beklenti varsa, çiftli klips kullanılması gerekmektedir.
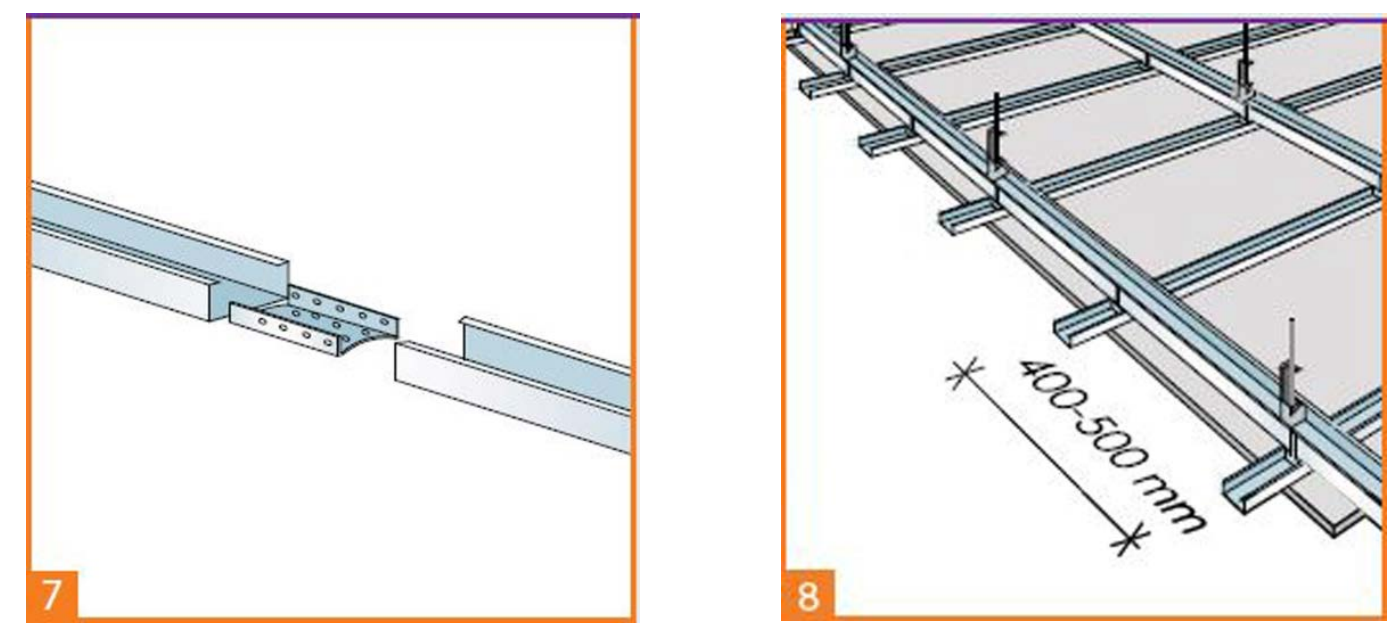

Şekil 18: Tali Tavan C Profillerinin Klips ile Sabitlenmesi (Saint-Gobain Rigips, 2013, s.164)

Monoblok Levhaların Montajı: Metal konstrüksiyonun tamamlanmasının ardından levhalar tali Taşıyıcı Tavan C profillerini ortalayacak şekilde vidalar ile monte edilir. Vidalar profillere en az 10 mm. girecek şekilde dik acı ile levhaları sabitlemelidir. (Şekil 19) 

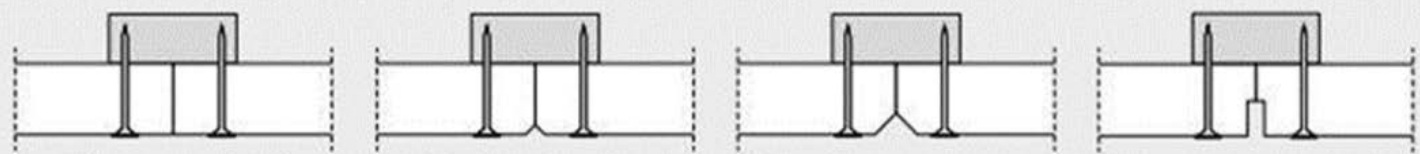

Şekil 19: Monoblok Taşıyıcı Sistemlerde Plaka Birleşim Gösterimleri (URL 1)

\subsubsection{Modüler Tavan Uygulamaları}

Asma tavan malzemesini taşıyan ızgara sistemi genelde her firmanın patent altında ürettiği değişik profilli alüminyum ya da galvanize bükme saclardan oluşmaktadır. Bunlar tavan kaplaması olarak seçilen asma tavan malzemesiyle birlikte kullanılacak şekilde özel olarak üretilmektedir. Ancak bunların askı sistemleri farklılık gösterebilir. Bu bağlamda Asma tavan malzemesini plaka, profil ve petekli şekillerde gruplandırmak mümkündür (Toydemir vd. 2000, s.370). Modüler Asma tavan uygulamaları en çok T taşıyıcılı olarak uygulanmaktadır. Bu sebeple adım adım aşağıda anlatılmaktadır. Levha şeklinde gizli taşıyıcılı olarak, özel taşıyıcılı profillerle lamel ve ızgara olarak uygulanabilmektedir.

$T$ Taşıyıcılı Tavan Uygulamaları: Ters $T$ profile oturan bu tür asma tavan sistemi uygulamalarında, taşıyıcı $\mathrm{T}$ profil, asma tavanın hemen altında olduğu için görünür (Berkin, 2020, s.98). Asma tavan oluşturulmadan önce planlama ve ölçme çok önemlidir. Tavan yüksekliği hesaplanırken önce döşeme altında oluşturulmuş kiriş, tesisat kanalları göz önüne alınarak tavan yüksekliği hesaplanır. Çünkü mekan içinde her dört köşedeki duvarların yükseklikleri zemin bozukluklarından dolayı farklı çıkabilmektedir. Ölçme ve işaretleme $T$ taşıyıcılı tavan uygulamalarının ilk aşamasıdır. Mekanın tavan planlaması tüm duvarlarda kiriş, kolon ve harici yapısal hareketleri içeren çizimi oluşturmaktadır. Bir yüzeyden başlayarak modüler olarak devam eden karolaj çizimi, karşı yüzeye geldiğinde yerleştirilecek levhanın boyutlarına dikkat edilmesi gerekmektedir. Oda ölçüldükten sonra tavan planı, dolayısıyla tavanın görsel planına karar verilmelidir (Şekil 20) (Saint-Gobain Rigips, 2013, s.167).

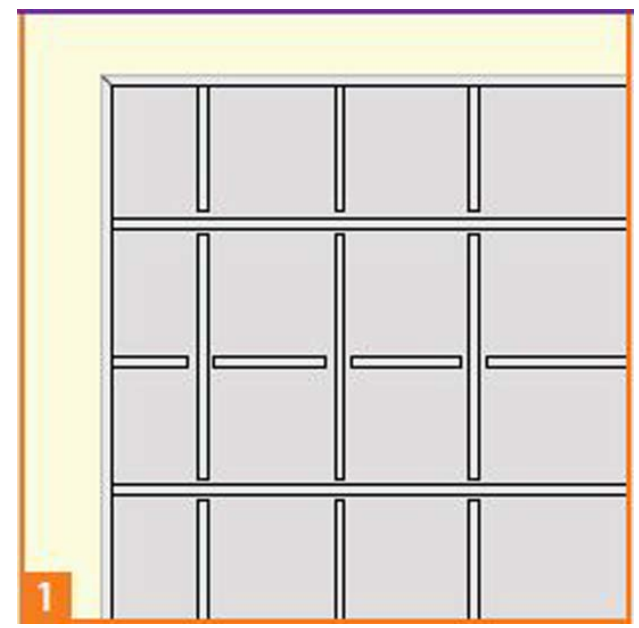

Şekil 20: Asma Tavan Karolajının Yapılması (Saint-Gobain Rigips, 2013, s.167)

Mimari projede oluşturulan asma tavan kesitine göre uygulama yapılacak tavan bitiş kotu lazer terazi veya hortum terazi ile işaretlenir. Konstrüksiyonun kurulması $T$ taşıyıcılı asma tavan uygulamalarının ikinci aşamasıdır. İşaretlenen hat boyunca duvar durumu ve döşenecek plaka tipine bağlı olarak çerçeve profili (C köşebent, L köşebent, Basamaklı köşebent gibi) öncesinde talep edilen tavan yüksekliğine göre duvara vidalanmaktadır (Şekil 21) (Saint-Gobain Rigips, 2013, s.168). 


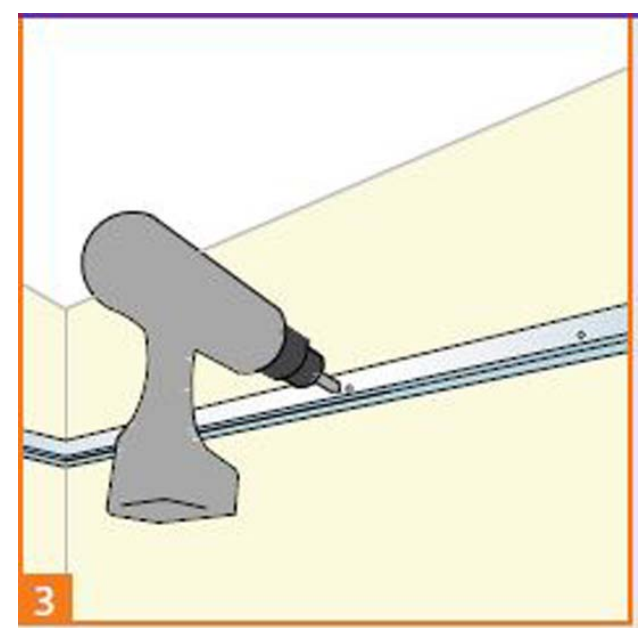

Şekil 21: Çerçeve Profilinin Sabitlenmesi (Saint-Gobain Rigips, 2013, s.168)

Mevcut tavan yüzeyine çelik dübeller projeye uygun olarak bağlanır. Askı çubukları da çelik dübelin L kıvrımına geçirilerek tavana taşıtılmaktadır. Asma tavan kotunu ayarlayabilmek için askı teline askı maşası (yaylı maşa) bağlanmaktadır. (Tavan yüklerinin sarkma yapmaması için askı çubukları sıkı bir şekilde bağlanmalıdır) Askı çubuklarının tavanda yerlerinin belirlenmesi uygulamanın başarısı açısından önemli bir yer tutmaktadır. Askı çubukları ana taşıyıcı T profilleri taşıyacağı için çelik dübellerin ilk aşamada tavana planlayarak yerleştirilmesi uygulamanın başarısı için gereken bir başka önemli koşuldur. Uygulamada askı çubuklarının konumlandırıması yapılırken tavanda mevcut veya yapılacak, aydınlatma, havalandırma, seslendirme vb. tesisat varsa çakışmaması sağlanmalı gerekli takviyeler yapılmalıdır (Şekil 22) (Saint-Gobain Rigips, 2013, s.168).

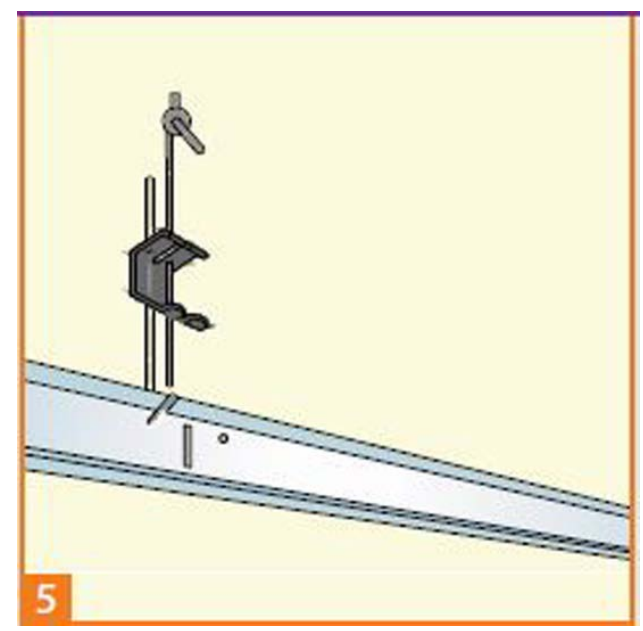

Şekil 22: Askı Maşasının Askı Çubuklarına Geçirilmesi (Saint-Gobain Rigips, 2013, s.168)

Askı çubukları ile mesafe ayarladıktan sonra, ana T15/T24 taşıyıcılar, 60x60 ızgara oluşturacak şekilde, $1200 \mathrm{~mm}$ Uzun Tali T profil Ana Taşıyıcı T profillere $600 \mathrm{~mm}$ aralıklar ile birbirine geçecek şekilde bağlantısı yapılmaktadır (Şekil 23) (Saint-Gobain Rigips, 2013, s.169). Tüm ana ve yardımcı T profiller birbirine dik olacak şekilde bağlantısı yapılmalıdır. Ölçüler tavsiye olarak verilmiş olup, ana taşıyıcı $T$ profiller istenilen uzunlukta kesilebilir, esas olan ana taşıyıcı ve yardımcı taşıyıcılarla ızgara oluşturulmasıdır. 

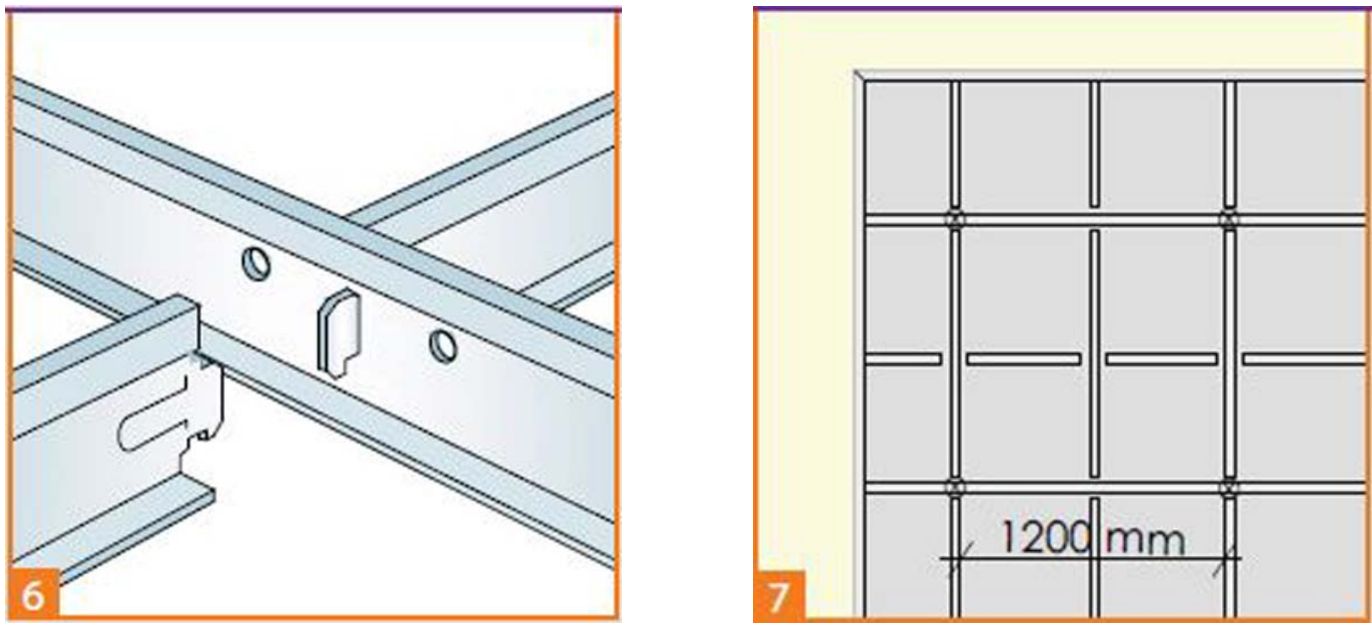

Şekil 23: Ana ve Tali Taşıyıcıların Montajı; Tavan Planı (Saint-Gobain Rigips, 2013, 169)

Tavan panellerinin montajı $\mathrm{t}$ taşıyıcılı asma tavan uygulamalarının son aşamasıdır. Tüm taşıyıcılar yerleştirildikten sonra, tavan teraziye getirilmektedir. Oluşturulan ızgara sistem için kenar detayına göre tavan panelleri takılmaktadır. Ana ve tali taşıyıcılar arasındaki açı her noktada birbirine mutlaka dik olması gereklidir. Takılan levhaların duvar diplerinde boyutları büyük geldiği takdirde yerinde kesilerek montajı yapılmaktadır (Saint-Gobain Rigips, 2013, s.169).

Gizli Taşıyıcılı-Klip in Modüler Asma Tavan Uygulamaları: Modüler sistemlerden biri olan gizli taşıyıcılı klip in modüler asma tavan sistemlerinin uygulamalarında genelde kullanılan sistem bileşenleri ve izlenen yol aşağıdaki gibidir. Bu tavan kaplamaları istenildiği zaman kullanıcı tarafından sökülüp takılabilir (Şekil 24).

Uygulama:

1. Mevcut tavan yüzeyine, çelik dübelli tavan pabucunun (7) projeye uygun olarak bağlantısı yapılmaktadır.

2. Çelik dübelli tavan pabucuna (7) askı teli (5) geçirildikten sonra, askı teline askı maşası (6) takılmakta, sonrasında çift delikli askı maşasına diğer yönde askı teli bağlanmaktadır.

3. Ana taşıyıcı gizli klip, profillere (2) takılan askı telleri (5) kot ayarı yapıldıktan sonra kesilmektedir. Gizli taşıyıcılı klip profillere 90 derece, diğer yönde yine klip, profillerin birleşim klipsi (4) ile bağlantısı yapıımaktadır.

4. Ana taşıyıcı klip, profiller en fazla $1200 \mathrm{~mm}$ aks aralıkları ile bağlanırken; yardımcı taşıyıcı klip profiller ise kullanılacak panel boyutuna göre düzenlenmelidir.

5. Klip, paneller (1) alt kotta yer alan yardımcı taşıyıcı klip profillerine bağlanmaktadır. 


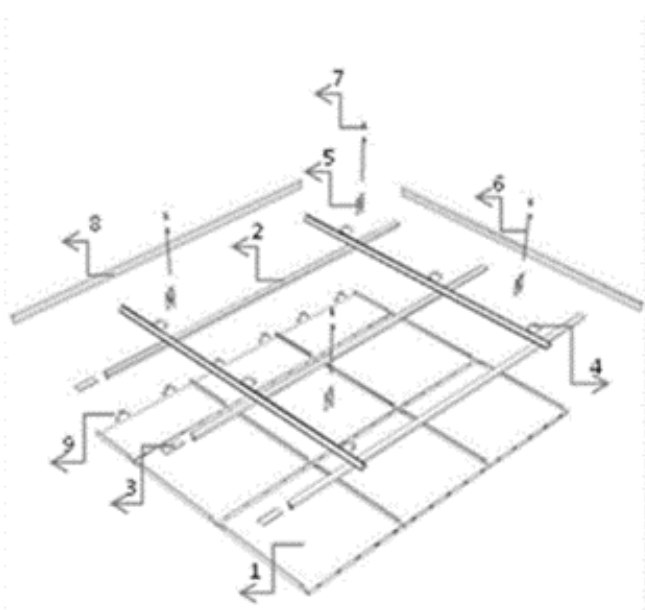

\section{Sistem Bileşenleri}

1.Gizli Kenarlı Panel

2. Ana Taşıyıcı Profil

3. Profil ekleme

4. Birleşim Klipsi

5. Askı Yayı

6. Askı Teli

7. Çelik Dübelli Tavan Pabucu

8.Köşebent

9.Kenar Takozu

Şekil 24: Gizli Taşıyıcılı (Klip-in) Asma Tavan Perspektif (URL 1)

Gizli Taşıyıcılı-Kancalı Modüler Asma Tavan Uygulamaları: Ters T profile sarkıtılarak oturan sistemde, taşıyıcı T profil, asma tavanın oluşturduğu fuganın içine gömülür ve net bir şekilde görülmez (Berkin, 2020, s. 99). Modüler sistemlerden biri olan gizli taşıyıcılı kancalı modüler asma tavan sistemlerinin uygulamalarında genelde kullanılan sistem bileşenleri ve izlenen yol aşağıdaki gibidir. Bu tavan kaplamaları istenildiği zaman kullanıcı tarafından sökülüp takılabilir (Şekil 25).

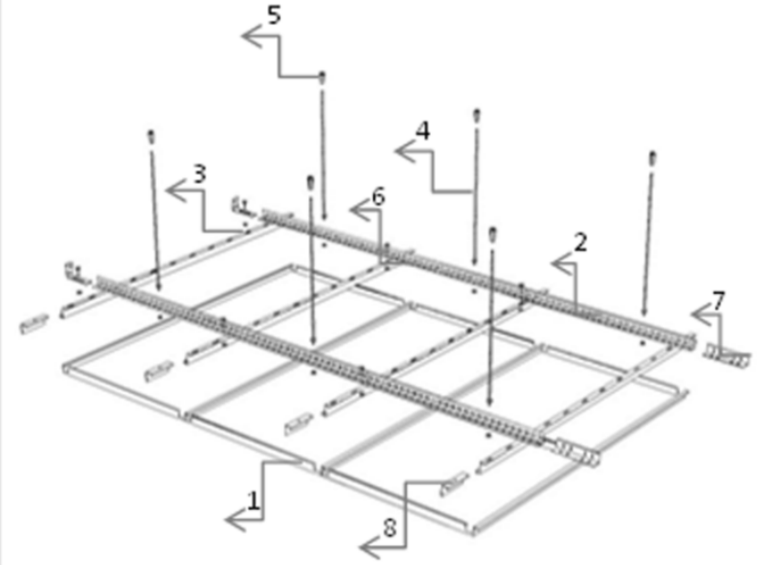

\section{Sistem Bileşenleri}

1.Kancalı Taşıyıcılı Plaka

2. Ana L Taşıyıcı Profil

3. Kancalı Profil

4. Askı Tiji

5. Tij Dübeli

6. Vida+Somun+Rondela

7. Ana L Ekleme parçası

8.Kancalı Ekleme parçası

9. Köşebent

\section{Kenar Takozu}

Şekil 25: Gizli Taşıyıcııı (Kancalı) Asma Tavan Perspektif (URL 1)

Uygulama

1. Mevcut Tavan yüzeyine tij dübelleri (5) projeye uygun olarak bağlanmaktadır.

2. Tij dübellerine askı tijleri (4) bağlanmaktadır.

3. Tij dübellerine ana $L$ taşıyıcı profili (2) asma tavan kotuna uygun olarak somun rondela ile monte edilmektedir. İki ana $L$ taşıyıcı profil arasındaki uzaklık en fazla $1200 \mathrm{~mm}$ olmalıdır.

4. Ana $L$ taşıyıcı profillerine (2) kancalı taşıyıcılı plakalara uygun ölçülerde kancalı taşıyıcı profili (3) vida somun rondela bile monte edilmektedir.

5. Kot ayarı yapıldıktan sonra uzun gelen askı tijleri kesilmektedir.

6. Kancalı taşıyıcı profillere plakalar bağlanmaktadır.

Lamel Kaplama Modüler Asma Tavan Uygulamaları: Modüler sistemlerden biri olan lamel asma tavan sistemlerinin uygulamalarında genelde kullanılan sistem bileşenleri ve izlenen yol aşağıdaki gibidir. Bu tavan kaplamaları istenildiği zaman kullanıcı tarafından sökülüp takılabilir. (Şekil 26) 
Uygulama

1. Mevcut Tavan yüzeyine çelik dübelli tavan pabucu (6) projeye uygun olarak bağlanmaktadır.

2. Çelik dübelli tavan pabucuna (6) askı teli (4) geçirildikten sonra, askı teline askı maşası (5) takılmaktadır. Çift delikli askı maşasına diğer yönde askı teli bağlanmaktadır.

3. Tırnaklı taşıyıcı profillere $(\mathrm{L}: 1800 \mathrm{~mm})$ (2) takılan askı telleri, kot ayarı yapıldıktan sonra kesilmekte, taşıyıcı profillerin devamlıığı talep edilirse, tırnaklı taşıyıcı profil ekleme (3) elemanı kullanılmaktadır.

4. İki Tırnaklı taşıyıcı profil arasında en fazla $1200 \mathrm{~mm}$ olmalıdır.

5. İstenilen aks aralığında düzenlenmiş tırnaklı taşıyıcı profillere bölmeli paneller (1) bağlanmakta, istek doğrultusunda bölmeli panellere bölme apakları (8) takılmaktadır. Panellerini uç uca eklenmesi talep edilirse, bölmeli panel ekleme (7) kullanılabilmektedir.

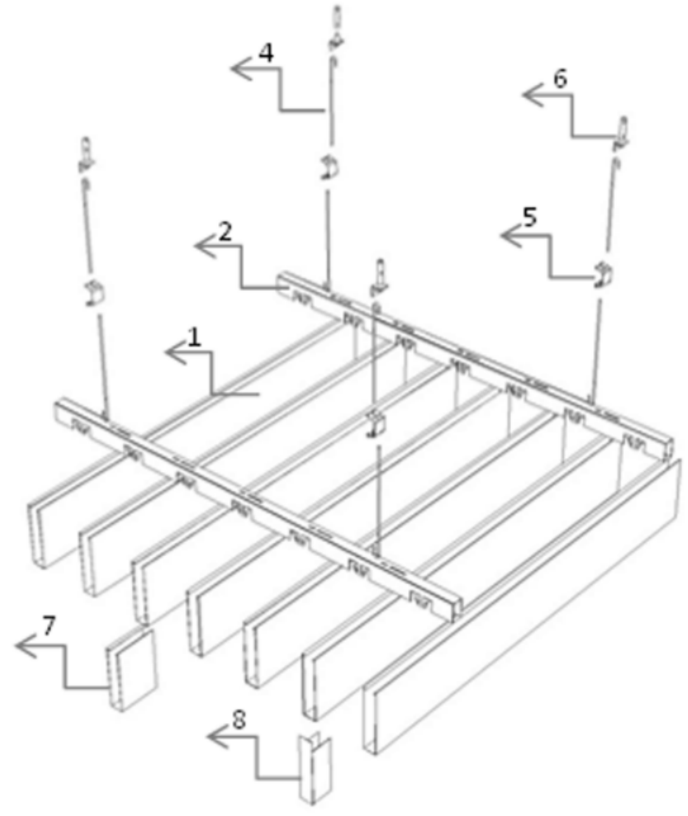

Şekil 26: Bölmeli Panel Kaplama Asma Tavan Perspektif (URL 1)

\section{Sistem Bileşenleri}

1.Baffle panel

2. Tırnaklı Taşıyıcı profil

3. Tırnaklı Taşıyıcı Profil Ekleme

4. Askı Teli

5. Askı Maşası

6. Çelik Dübel

7. Bölmeli panel ekleme

8.Bölmeli kapak

Izgara Kaplama Modüler Asma Tavan Uygulamaları: Modüler sistemlerden biri olan lamel asma tavan sistemlerinin uygulamalarında genelde kullanılan sistem bileşenleri ve izlenen yol aşağıdaki gibidir. Bu tavan kaplamaları istenildiği zaman kullanıcı tarafından sökülüp takılabilir (Şekil 27).

Uygulama

1. Mevcut tavan yüzeyine çelik dübelli tavan pabucunun (7), projeye uygun olarak bağlantısı yapılmaktadır.

2. Çelik dübelli tavan pabucuna (7) askı teli (5) geçirilir. Askı teline askı maşası (6) takııı. Çift delikli askı maşasına diğer yönde askı teli bağlanmaktadır.

3. Ana taşıyıcı profillere (L:1800 mm) (2) takılan askı telleri, kot ayarı yapıldıktan sonra kesilir. 90 derece yönünde, iki ana taşıyıcı profil arasına, yardımcı taşıyıcı profiller (3) (L:1200 mm aralıkla) bağlanmaktadır.

4. $1200 \mathrm{~mm}$ boyundaki yardımcı taşıyıcı profiller (3) arasına, 90 derece yönünde yardımcı taşıyıcı L: $600 \mathrm{~mm}$ 'lik profiller (4) monte edilmektedir.

5. Izgara plakalar $\left(600^{*} 600 \mathrm{~mm}\right)$ (1) panelleri oluşturulan karkas sistemine bağlanmaktadır. 


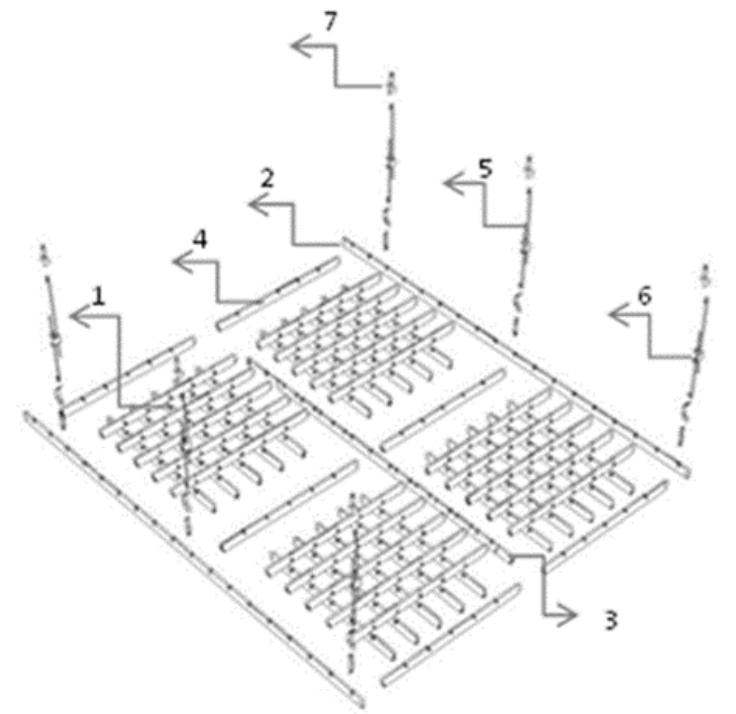

\section{Sistem Bileşenleri}

1. Izgara Plaka $600 * 600 \mathrm{~mm}$

2. Ana Taşıyıcı profil L:1800 mm

3. Tali Taşıyıcı Profil L:1200 mm

4. Tali Taşıyıcı Profil L:600 mm

5. Askı Teli

6. Askı Maşası

7. Çelik Dübelli Tavan Pabucu

8. Ana Taşıyıcı profil ekleme

9. Köşebent

\section{Sonuç}

Şekil 27: Izgara Kaplama Asma Tavan Perspektif (URL 1)

İ̧ mekandaki bitiş yüzeylerinden biri olan asma tavanlar, kullanıldığı mekanlarda estetik, mekânsal konfor ve kullanıcı gereksinimlerini birinci dereceden karşılayan yapı bileşenleridir. Kullanıldığı yapıda mekanın, akustik konfor, yangın dayanımı, nem dayanımı, ISı yalıımı gibi birçok işleve yanıt vermektedir. Mekanlarda uygulanacak asma tavan sisteminin seçiminin doğru yapılması yanında, uygulamasının da doğru yapılması elde edilecek sonuç açısından önemlidir. Yapılan kaynak taramalarında, asma tavanların bir bütün olarak ele alınmadığı, eldeki bilgilerin sistematik olarak değerlendirilmediği, bunun da önemli bir eksiklik yarattığı görülmüştür. Bu noktada hareketle makale kapsamında, iç mekanlarda kullanılan asma tavan türleri ve uygulamalarının sistematik olarak ele alınması amaçlanmış̧ır. Asma tavan sistemlerinin seçim ölçütleri bu çalışma dışında bırakılmış, bir bütün olarak ele alınmasına odaklanıımıştı. Asma tavan sistemlerinin seçiminde, mekanın işlevine ve mekandan beklenen başarım ölçütlerine bağlı olarak belli ölçütler çerçevesinde seçimin yapılması doğru sonuçlar vermektedir. Çalışmanın başında asma tavanlardan beklentiler alt başıılar halinde ve kısaca ele alınmıştır. Özellikle mekanların işlevine bağlı olarak bazı beklentilerin sağlanması, diğerlerine göre daha önemli hale gelebilmektedir. Bu koşullarda beklenen başarım düzeyini sağlayacak doğru malzeme ve sistemin seçilmesi beklenen başarımın elde edilebilmesi açısından önemlidir. Bu çalışma kapsamında, tanımından başlayarak, asma tavanlardan beklentilerin neler olduğu, bileşenleri, türleri ve uygulama biçimleri sırasıyla ele alınmış, anlatımı kolaylaştırmak için bol fotoğraf ve çizimle desteklenmiştir. 


\section{Kaynaklar}

Allen, Edward; Iano, Joseph, Fundamentals of Building Construction: Materials and Methods, 5. B., John Willey and Sons, New Jersey 2009.

Berkin, Genco, İç Mimarlıkta Malzeme ve Detay, 2.B., YEM Yayın, İstanbul 2020.

Brandolese, Sara; Fiorin, Laura; Scotta, Roberto, "Seismic Demand and Capacity Assessment of Suspended Ceiling Systems", Engineering Structures, (193), 2019, s. 219-237.

Cavanaugh, William, J. "Introduction to Architectural Acoustics and Basic Principles", Architectural Acoustics: Principles and Practice, Ed.: Cavanaugh, W. J., Wilkes, J. A., 1. B., John Willey and Sons, New York 1999, s. 1-54.

Chou, Tien-Lun; Tang, Chieh-Hsin; Chuang, Ying-Ji; Lin, Ching-Yuan, "Study on Smoke Leakage Performance of Suspended Ceiling System", Sustainability, 12 (7244), 2020.

Coşar, Nihat, Döşeme Kaplamalarının İşlevsellik Açısından İncelenmesi, Yüksek Lisans Tezi, İ.T.Ü. Fen Bilimleri Enstitüsü, İstanbul 2002.

Dhakal, Rajesh, P.; MacRae, Gregory; Pourali, Atefeh; Paganotti, Giacomo, "Seismic Fragility of Suspended Ceiling Systems Used in NZ Based on Component Tests", Bulletin of the New Zealand Society for Earthquake Engineering, 49 (1), 2016.

Erdem, Nurşah, Restoranların Tasarımında Aydınlatma ve Renk, Yüksek Lisans Tezi, Yıldız Teknik Üniversitesi Fen Bilimleri Enstitüsü, İstanbul 2017.

Hasol, Doğan, Ansiklopedik Mimarlık Sözlüğü, 4. B., YEM Kitapevi, İstanbul 1990.

Hegger, Manfred; Auch-Schwelk, Volker; Fuchs, Mathias; Rosenkranz, Thorsten, Constructial Materials Manual, 1.B., Birkhauser, Münich 2006.

Gravit, Marina; Golub, Elena; Grigoriev, Denis; Ivanov, Igor, "Fireproof suspended ceilings with high fire resistance limits", Magazine of Civil Engineering, (8), 2018, ss. 75-85.

Gürel, Nihan, İlköğretim Okullarının Akustik Açıdan İncelenmesi: İstanbul'da Bir İlköğretim Okulu Örneği', Yüksek lisans tezi, İstanbul Teknik Üniversitesi Fen Bilimleri Enstitüsü, İstanbul 2007.

Mütevellioğlu, Gülser, Asma Tavanların Akustik Yönden İncelenmesi, Yüksek Lisans Tezi, Yıldız Teknik Üniversitesi, Fen Bilimleri Enstitüsü, İstanbul 1995.

Pracki, Piotr; Dziedzicki, Michal; Komorzycka, Paulina, "Ceiling and Wall Illumination, Utilance, and Power in Interior Lighting", Energies, 13 (4744), 2020.

Ryu, Ki, Pung; Reinhorn, Andrei, M. "Analytical Study of Large-Area Suspended Ceilings", Journal of Earthquake Engineering, 23 (4), 2019, s. 592-624.

Ryu, Jonkwan; Hansol, Song; Yonghee, Kim, "Effect of the Suspended Ceiling with Low-Frequency Resonant Panel Absorber on Heavyweight Floor Impact Sound in the Building", Building and Environment, 139, 2018, s. 1-7. 
Saint-Gobain Rigips Alçı Sanayi ve Ticaret A.Ş, Genel Teknik Katalog, Ankara, 2013.

Sarıdoğan, Serhan, Farklı Tür ve Nitelikteki Asma Tavan Sistemlerinin Sismik Performansının Sarsma Tablası Deneyleri ile Belirlenmesi, Yüksek Lisans Tezi, Dokuz Eylül Üniversitesi Fen Bilimleri Enstitüsü, İzmir 2013.

Soroushian, Siavash; Maragakis, E. Manos; Jenkins, Craig, "Capacity Evaluation of Suspended Ceiling Components, Part 1: Experimental Studies", Journal of Earthquake Engineering, 19:5, 2015, s. 784-804.

Tichelmann, Karten; Pfau, Jochen, Dry Construction: Principles, Details, Examples. Detail Practice Birkhauser, Basel 2012.

Toydemir, Nihat; Gürdal, Erol; Tanaçan, Leyla, Yapı Elemanı Tasarımında Malzeme, Literatür Yayınları, İstanbul 2000.

TS EN 13964, Asma Tavanlar Gerekler ve Deney Yöntemleri. Türk Standartları Enstitüsü, Ankara 2014.

Ülker, Selen, Isı Yalıtım Malzemelerinin Özelliklerinin Uygulamaya Etkileri, Yüksek Lisans Tezi, İ.T.Ü. Fen Bilimleri Enstitüsü, İstanbul 2009.

Wieckowski, Andrzej; Ryz, Karol; Sikora, Wojciech, "Failures of Suspended Ceilings and Execution Errors", Technical Transactions Civil Engineering, 12, 2018, ss.107-116.

Yao, George, C. "Seismic Performance of Direct Hung Suspended Ceiling Systems", Journal of Architectural Engineering, (3), 2000, s. 6-11.

Yıldırım, Nadir, "Nanocellulose in Ceiling Tile," BioResources, 13 (4), 2018, s.73607370.

Yıldız, Özgür; Dal, Murat, "İnşaat Mühendisliği Uygulamalarında Su-Nem Kaynaklı Hasarların Değerlendirilmesi”, Tunceli Üniversitesi Bilim ve Gençlik Dergisi, 4 (1), 2016, ss.25-37.

\section{İnternet Kaynakları}

URL 1. ASPEN Yapı Zemin A.Ş (https://www.aspen.com.tr/) (Er: 01.01.2021)

URL 2. https://www.cumhuriyet.com.tr/haber/istanbulda-bir-hastanenin-tavani-coktu-3yarali-1759999 (Er: 01.01.2021) 